CERE Working Paper, 2020:6

\title{
Stated Willingness to Pay for Residential Renewable Electricity and Green Jobs in Aguascalientes, Mexico
}

\author{
Adan L. Martinez-Cruz and Hector Nuñez
}

The Centre for Environmental and Resource Economics (CERE) is an inter-disciplinary and inter-university research centre at the Umeå Campus: Umeå University and the Swedish University of Agricultural Sciences. The main objectives with the Centre are to tie together research groups at the different departments and universities; provide seminars and workshops within the field of environmental \& resource economics and management; and constitute a platform for a creative and strong research environment within the field.

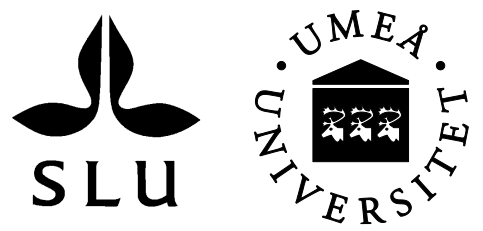




\title{
Stated Willingness to Pay for Residential Renewable Electricity and Green Jobs in Aguascalientes, Mexico
}

\author{
Adán L. Martínez-Cruz ${ }^{\mathrm{a}, \mathrm{b}, \mathrm{c}}$ and Héctor M. Núñez ${ }^{* b}$ \\ ${ }^{a}$ Department of Forest Economics and Centre for Environmental and Resource \\ Economics (CERE), Swedish University of Agricultural Sciences (SLU), Sweden \\ ${ }^{b}$ Department of Economics, Centro de Investigacion y Docencia Economicas \\ (CIDE), Mexico \\ ${ }^{\mathrm{c}}$ Center of Economic Research (CER-ETH), ETH Zurich, Switzerland
}

Highlights:

- A stated choice experiment is conducted in Aguascalientes's residential sector

- Residential consumers support a 30\% renewable electricity share

- Residential consumers support creation of new green jobs

- These findings provide useful information for a just energy transition policy

${ }^{*}$ Corresponding author. E-mail address: hector.nunez@cide.edu. Permanent address: Circuito Tecnopolo Norte 117, Aguascalientes, AGS, Mexico, CP 20313 


\begin{abstract}
Via a discrete choice experiment, this paper documents that residential electricity consumers in Aguascalientes, Mexico, are willing to pay a premium for renewable energies as well as for the creation of green jobs. These results are particularly timely because the current Federal administration has redirected priorities from an energy transition that was expected to boost renewable energies to the pursuing of energy sovereignty. Concerns regarding this prioritization have been raised by national and international stakeholders due to its potential economic inefficiency and its implications for the achievement of climate change goals. These concerns have only intensified as discussions begin on how Mexico should face the post-coronavirus recession. This paper's findings open the door to discuss whether a combination of a just energy transition together with the boosting of renewable energies should be part of a strategy to reach energy sovereignty at the same time that Mexico deals with a post-coronavirus world.
\end{abstract}

Keywords: Residential renewable electricity demand; just energy transition; post-coronavirus policy; energy sovereignty; Mexico; discrete choice experiment.

JEL codes: Q42, Q48, Q51.

\title{
1 Introduction
}

As part of the global commitment to tackle climate change, Mexico's Congress approved in 2012 the General Law on Climate Change which mandates the crafting of a comprehensive long-term national climate policy. Following suit, 2015's Energy Transition Law aims to transform Mexico's energy sector by liberalizing the market and adopting clean energy technologies and targets, including decarbonization strategies for the electricity sector (SENER, 2018b).

Since 2018, a change in Federal administration has led to new priorities. The focus is now on energy sovereignty - a concept reflecting the intention of bringing the energy industry back under government control (Gross, 2019). Although in general energy sovereignty does not entail a trade-off against sustainability, the current Federal administration has implemented 
measures that effectively slow down the energy transition. Two instances of such measures are the cancellation of what would have been Mexico's fourth clean energy auction, and the modernization of existing power plants which primarily run on coal, fuel oil, and natural gas (Davis, 2019). In addition, remarks from Mexico's president suggest a preconception against renewable energies - in referring to a wind power plant built with support from Federal and State governments during a previous administration, the president has described it as an example of visual pollution that only generates benefits to private owners who sell energy to consumers in USA (Infobae, 2020).

Although the country maintains international agreements or contracted commitments, this change in priorities was received with concerns from both national and international stakeholders due to its negative implications for climate change goals, its potential economic inefficiency, and the uncertainty it generates (Davis, 2019; Gonzalez, 2019; Nava, 2020; Proceso, 2020; Stromsta, 2019). Such concerns have only intensified as discussions begin on how Mexico should face the post-coronavirus recession (see Castañeda-Morales, 2020; Levy, 2020).

In this context, two policy-relevant findings are highlighted in this document. First, residential electricity consumers in Aguascalientes City report that they are willing to pay a bimonthly premium between 23 and 108 Mexican pesos (2018 MXP) for an increase in the share of renewable energy in their electricity mix. Second, consumers are also willing to pay a bimonthly premium of MXP 59 for the creation of green jobs. According to our findings, a policy that achieves a $30 \%$ biomass share together with the creation of 1,000 new green jobs would generate benefits among residential consumers in Aguascalientes, Mexico, equivalent to MXP 63 (USD 3.28) on a bimonthly basis. $^{1}$

Strictly speaking, these findings hold for consumers responding our sur-

\footnotetext{
${ }^{1}$ Assuming an exchange rate of 19.22 MXP/USD which was the average closing price in 2019 (Macrotrends, 2020).
} 
vey in Aguascalientes city, and further research is necessary to claim national or other scale representativeness. With this caveat in mind, we believe that this paper's findings highlight an opportunity that the current administration may be overlooking when pursuing energy sovereignty. That is, societal benefits can be generated through a policy that simultaneously boosts renewable energies and encourages that workers currently employed in fossil fuel-based industries transition to jobs in renewable energy-based industries. The latter goal is at the core of a just energy transition - a concept that has been put forward to guide the designing of strategies that aid those whose jobs, income, and livelihoods are at risk as the world pursues sustainable pathways (Rosemberg, 2017). Such a policy is also useful in overcoming the post-coronavirus recession in Mexico - and, in this sense, policy implications from this paper may help other countries as they face the challenge of overcoming the post-coronavirus recession while maintaining the goal of achieving energy transitions.

This paper's findings arise from the implementation of a Discrete Choice Experiment (DCE) presenting respondents to four alternatives. One alternative is the status quo option, and the other three are described in terms of four attributes. The first attribute is the source of renewable energy — solar, biomass, and a 50/50 mix of both. The second attribute is the share of renewable energy (from any source) in current electricity mix $-10 \%, 20 \%$, and $30 \%$. The third attribute is number of green jobs - 100, 1,000, and 2,000-, described as new jobs created in the renewable energy sector.

The price attribute is presented as an increase in respondents' self-reported bimonthly electricity bill $-5 \%, 20 \%$, and 40\%. By including the status quo alternative, the DCE implicitly allows the consumer to opt in into a contract through which he/she would compensate for increases in his/her preferred attributes. 


\section{Previous studies}

There is a well-established literature on stated preferences for residential renewable electricity. Findings from this literature have been consolidated in one literature review (Oerlemans et al., 2016), and four meta-analyses (Ma et al., 2015; Soon and Ahmad, 2015; Sundt and Rehdanz, 2015; Pokhrel, 2016). Through this section, when referring to these five studies altogether, we call them synthesizing studies. Oerlemans et al. (2016) carry out a literature review of 57 studies implementing a contingent valuation $(\mathrm{CV})$ protocol to estimate WTP for residential renewable electricity — with a focus on identifying areas of potential improvement to deliver more reliable estimates.

The four meta-analyses differ in the welfare measures under analysis. Also, the number and subset of primary studies are different —although the subsets largely intersect. Ma et al. (2015) analyze 142 WTP estimates expressed as perpetual payment per $\mathrm{kWh}$ (in 2006 USD), and reported in 29 primary studies. Pokhrel (2016) studies 99 WTP estimates measured as monthly 2008 USD per household, obtained from 21 primary studies. Soon and Ahmad (2015) focus on 124 WTP estimates expressed as monthly 2013 USD per household, reported in 30 primary studies. Sundt and Rehdanz (2015) analyze 85 WTP estimates reported by 18 primary studies, and expressed either as monthly 2010 USD per household or US-cents per kWh.

In terms of empirical methods, these synthesizing studies report that CV and DCE are the two most common methods collecting stated preferences for residential renewable energy. CV studies have predominantly used dichotomous choice and open-ended questions to elicit WTP (Oerlemans et al., 2016). More recently, vignette designs have made their way into this literature. A vignette study uses short descriptions of situations or persons (vignettes) that are shown to respondents in order to elicit their judgments about these scenarios (Atzmüller and Steiner, 2010). ${ }^{2}$ Researchers have im-

\footnotetext{
${ }^{2}$ Vignette scenarios resemble alternatives presented by DCE in the sense that they are
} 
plemented vignette designs to explore household's preferences for electricity mixes (that may include renewable energies) in post-Fukushima Japan (Rehdanz et al., 2017), and residential consumers' preferences for renewable energies and supply reliability in Germany and Great Britain (Merk et al., 2019).

In terms of geographical coverage, all five synthesizing studies report that stated preferences for residential renewable energy have been studied mostly in the U.S., Canada, some EU countries, China, South Korea, and Japan (Sundt and Rehdanz, 2015; Soon and Ahmad, 2015). Latin America, Africa, and in general less developed countries are the regions with the least number of studies.

Publication bias seems to not be present in the literature documenting stated WTP for residential renewable electricity. ${ }^{3}$ In the context of studies estimating stated WTP for residential renewable electricity, it is important that authors and journals report not only positive, statistically significant estimates but also zero-WTP and negative WTP estimates - as these values are theoretically feasible as well. Focusing on different subsets of primary studies, Ma et al. (2015) and Soon and Ahmad (2015) report Begg's test statistics that suggest lack of publication bias.

Results highlighted by the meta-analyses include i) residential consumers' WTP for renewable electricity differs depending on the source of energy with solar and wind energies being more valued than hydropower and biomass (Ma et al., 2015; Sundt and Rehdanz, 2015); ii) metropolitan residents report higher WTP than their rural counterparts (Soon and Ahmad, 2015); iii) U.S. and Canada residents report higher WTP than residents in other parts of the

designed to experimentally vary the levels of theoretically important vignette characteristics (or attributes).

${ }^{3}$ The term publication bias refers to the systematic preference (from either authors or journals or both) to select publications that report statistically significant associations between the outcome variable and the explanatory variable of main interest in a research project. 
world (Soon and Ahmad, 2015; Sundt and Rehdanz, 2015); iv) respondents' socioeconomic characteristics (e.g. income, electricity consumption level) and knowledge about renewable energies are relevant to explain heterogeneity in WTP (Ma et al., 2015; Pokhrel, 2016; Soon and Ahmad, 2015; Sundt and Rehdanz, 2015); and v) characteristics of the study itself statistically explain variations in the WTP (Ma et al., 2015; Pokhrel, 2016; Soon and Ahmad, 2015; Sundt and Rehdanz, 2015). ${ }^{4}$

The meta-analyses reach different conclusions in two realms. First, while Soon and Ahmad (2015) report that DCE studies yield lower estimates than CV studies, the opposite direction is reported by Ma et al. (2015); Pokhrel (2016) and Sundt and Rehdanz (2015). Second, they differ in terms of their conclusion with respect to the reliability of benefit transfers based on their corresponding meta-regressions. ${ }^{5}$ Ma et al. (2015) cautions against benefit transfer because their analysis yields that characteristics of the study design weigh more than other factors when explaining variation in WTP. Pokhrel (2016) documents that a unit value transfer with income adjustment outperforms several meta analytic strategies. Soon and Ahmad (2015) do not pursue the transfer of benefits - deeming it controversial. With the caveat that their transfers are unreliable when dealing with biomass, Sundt and Rehdanz (2015) report a median percentage error of $21 \%$ for the transfer of WTP per household per month -an error that falls within previous reported ranges.

\footnotetext{
${ }^{4}$ The impact from studies' design is an undesirable result — as ideally the instrument with which data is collected is expected to be uninformative of the resulting estimates. However, an advantage of a meta-analysis is that researchers can learn how important the instrument is itself and take it into consideration accordingly.

${ }^{5}$ In this paper's context, benefit transfer refers to estimating WTP for residential renewable electricity for a population for which no primary data is available. Such estimation is carried out by transferring estimated obtained on a different population that, under specific assumptions, is deemed informative of the unstudied population.
} 


\section{$3 \quad$ Energy policy in Mexico}

\subsection{Energy Transition: 2013-2018}

Mexico's previous administration (2013-2018) signed international environmental agreements and pushed an energy reform at a high political cost to promote a competitive market across the whole supply chain in the electricity and fuel markets, with renewable energy as one of the priorities. Mexico's environmental goals were set to an unconditional $22 \%$ reduction of the greenhouse gases (GHG) emissions respect to a baseline scenario by 2030, and specifically a $31 \%$ GHG emissions reduction by the generation electricity sector by the same year (updated 2018 "General Law on Climate Change").

Concurrently, Mexico committed to an energy transition. In 2015, through the Energy Transition Law (ETL), the Mexican government committed to $30 \%$ of clean electricity by 2021 -and 35\% by 2024 (Mexican 2015 "Energy Transition Law"). As a result, Mexico increased the production of clean electricity at a rate of $4.8 \%$ annual average from 2014 to 2018, and reached a $23.1 \%$ share into the electricity mix of which $28 \%$ corresponds to efficient co-generation and nuclear power and the remaining $72 \%$ to renewable sources (SENER, 2019, 2018d). Renewable power increased by only $1.0 \%$ over the same period, while its contribution to the electricity supply decreased from $18 \%$ to $16 \%$. These two issues relate to the reduction in hydropower generation. However, the installed capacity of other sources (i.e. wind, geothermic, biomass, solar, and biogas) has dramatically increased. For instance, solar and biogas installed capacity went up from $461 \mathrm{MW}$ and $89 \mathrm{MW}$ in 2017 to 1647 MW and 217 MW in 2018, respectively (SENER, 2018e). Their potential is still quite large, solar and bioenergy estimated installed capacity will be 11,661 MW and 1,478 MW by 2032, respectively SENER (2018b). It is worth noticing that solar isolation in Mexico is larger than $5 \mathrm{kWh} / \mathrm{m} 2 /$ day, one of the largest worldwide (Hancevic et al., 2017).

In intersection with the clean energy goals, ETL has promoted natural 
gas (NG) use in new power plants as well as modernization of existing conventional plants under the argument that NG is cleaner than other fossil fuels and price is significantly lower. This transition includes to shut down high emission power plants, like coal-fired power plants. From an aggregated point of view, it is expected new green jobs to be able to compensate job losses from closed down plants, but at regional level this does not necessarily hold. For instance, coal-fired power plants in the states of Coahuila and Guerrero are expected to be retired by 2030, which will affect directly local communities, since plants and coal mines represent the most important source of jobs in the region.

Finally, ETL aims to promote a competitive market across all the supply chain in the electricity and fuel markets. In the former case, the first step has been to let private companies enter to power market and compete with CFE. The previous administration implemented three successful auctions to add 7 GW of energy (about $6 \%$ of the projected installed capacity in 2032) from solar, wind, and geothermal to the system in the following 15 to 20 years (SENER, 2019). In addition to the auctions, there are two other schemes to promote the development of renewable energies. First, the introduction of Clean Energy Certificates, which were created to ensure increasing annual shares of clean energy market. Second, promotion of distributed generation projects for the residential sector. The latter alternative has made small progress in the country and a massive program can threat financial viability of electricity companies (see Hancevic et al., 2019).

The following transition steps should allow private companies to compete in the rest of the supply chain, including the retail market. A change in tariff scheme would have been required to let private retailers offer a competitive portfolio to consumers with a large variety of characteristics. For instance, one scheme that includes shares of renewable as part of the electricity sold. However, such change will face a high obstacle. As mentioned, residential electricity consumption in Mexico is heavily and horizontally subsidized 
through a increasing block tariff (IBT) schedule. On average, households only pay $46 \%$ of the total cost of the service -i.e., generation, transmission, distribution and retail costs. Reducing this subsidy would imply high political costs for any administration, so the one in turn usually maintains the IBT schedule unchanged.

\subsection{New energy sovereignty: 2019-}

The current administration (2019-2024), which was elected in 2018 with a vast majority, has redirected Mexico's priorities. In particular, the focus is now on energy sovereignty - aiming to bring the energy industry back under government control through the monopoly publicly owned company (CFE) and decreasing imports of refined fuels (Gross, 2019). One of the first signals of the new direction has been to hold up the fourth auction indefinitely. The federal government argues that renewable energy is too expensive because needs from cheap fossil fuel power to connect to the grid and only benefits some few private companies (e.g. Méjia and Saldaña, 2019; Infobae, 2020). Although it has committed to comply with the clean energy goals, it is expected to do it using more NG than renewable energies. Another important signal has been to invest significant resources both in the CFE to build new fossil fuel based plants, to renew some of the current power plants, and to postpone some shutting down plans, including the coal-fired power plants. Fossils have also been boosted by important investments from the government to the oil company (PEMEX) and the building of a major oil refinery, which is expected to be ready by $2023 .{ }^{6}$

Nevertheless, electric sovereignty is in question still. NG is the main fuel used for electricity generation in Mexico (68\%). Mexico currently imports more than $60 \%$ of the NG required to satisfy domestic demand mainly from

\footnotetext{
${ }^{6}$ See report from president López Obrador after his first year of administration in "Primer Informe de Gobierno" at https://frameworkgb.cdn.gob.mx/informe/Informe_Gobierno_de_Mexico.pdf
} 
the U.S., and the electricity sector claims more than $50 \%$ of that amount (SENER, 2018c, 2019). This trend is expected to remain at a similar level in the coming years (SENER, 2018c). As explained above, the high levels of NG consumption are explained in part by the transition toward cleaner and cheaper fuels in recent years and the low NG price in the US (SENER, 2018d).

\subsection{Renewable energies in Aguascalientes}

Mexico government follows a federal system under which states and municipalities have certain autonomy to legislate in matters that are not the exclusive competence of the federation and to spend autonomously some resources. For this case, states and municipalities may take further steps to support renewable energies, and therefore green jobs in their regions. Incentives includes but are not limited to property tax exemptions to renewable plants and/or their tier companies, training human capital on energy issues at the states universities, waste recovering and recycling policies, among others. Conversely, they cannot take direct measures on CFE like to avoid power plants' close downs.

The city of Aguascalientes is the capital of the state with the same name, it has an area of $385 \mathrm{~km} 2$ and about 1 million residents. It is located in a semi-arid region, with a high potential and an installed capacity for solar and a medium-high potential for biomass (IRENA, 2018; SENER, 2018a,d). Aguascalientes state is home for two $250 \mathrm{MW}$ solar parks already connected to the grid and will host about additional 570 MW (SENER, 2019). The state is estimated to have an annual power generation potential of $1350 \mathrm{TJ}$ from urban solid waste and wastewater, which is a high potential for a small region (SENER, 2018a). In addition, the local government is committed to encourage renewable energy further, for instance, by promoting human resources training at state universities, incentivizing PV solar parts companies, 
and launching a new waste processing facility for power generation and other uses.

Whereas the federal government seems to slow down renewable energy progress in the country, other groups such as state governments could take steps forward to support it and to comply the ETL and General Law on Climate Change. CFE can buy this energy and eventually federal administration will realize that consumers are willing to pay for it. To the best of our knowledge there is no previous source of information to support policy recommendations on this issue. Hence one justification for our study.

\section{Theoretical and empirical approaches}

\subsection{Random Utility Model}

The Random Utility Model (RUM) provides theoretical support to the empirical analysis of discrete choice experiments (see Train, 2009). The departure point of the RUM is that, when faced to $J$ mutually exclusive alternatives, individual $i$ chooses the alternative that provides him/her with the highest utility. An individual's indirect utility from each alternative is denoted as $U_{i j}$ for $i=1,2, \ldots, I$ and $j=1,2, \ldots, J$. The individual is assumed to know his/her own utility function with certainty. The researcher, however, cannot fully observe each $U_{i j}$. Thus, from the researcher's point of view and once a linear indirect utility function is assumed, $U_{i j}$ can be expressed as

$$
U_{i j}=V_{i j}+\epsilon_{i j}=\beta^{\prime} x_{i j}+\epsilon_{i j}
$$

where $V_{i j}$ is the component observed by the researcher; $x_{i j}$ is a $(M+1) X 1$ column vector denoting $M$ alternative-specific attributes and the alternativespecific intercept; $\beta$ is a $(M+1) X 1$ column vector representing the alternativespecific intercept, and the preferences for the alternative-specific attributes; and $\epsilon_{i j}$ represents the purely random heterogeneity that the researcher is unable to observe. 
If an individual chooses the alternative associated to the highest utility, then the individual $i$ chooses $U_{i}^{\max }$, where

$$
U_{i}^{\max }=\max \left\{U_{i 1}, U_{i 2}, \ldots \ldots, U_{i J}\right\}
$$

The willingness to pay (WTP) for the alternative associated to the highest utility is expressed as the monetary value of the utility derived from $U_{i}^{\max }$, i.e.,

$$
W T P_{i}=\frac{U_{i}^{\max }}{\beta_{p}}
$$

where $W T P_{i}$ is individual $i$ 's WTP; and $\beta_{p}$ is the price preference parameter. Under the assumption that indirect utility is linear in attributes, including income, $\beta_{p}$ is the negative of the marginal utility from income.

Under the assumptions embedded in equation (1), a researcher cannot observe $U_{i}^{\max }$ as defined in equation (2). A researcher can only make statements in terms of expected utilities which are calculated over the error term $\epsilon_{i j}$, i.e.

$$
E\left(U_{i}^{\max }\right)=E_{\epsilon}\left[\max \left\{V_{i 1}, V_{i 2}, \ldots \ldots, V_{i J}\right\}\right]
$$

Under the assumption that $\epsilon_{i j}$ follow a type I extreme value distribution, the expected maximum utility can be calculated through the logsum formula, ${ }^{7}$ i.e.

$$
E\left(U_{i}^{\max }\right)=\ln \sum_{j=1}^{J} \exp \left(V_{i j}\right)
$$

Accordingly, statements involving welfare measures are made in expected terms. For a before $(b)$ and an after $(a)$ situations - where after implies a

\footnotetext{
${ }^{7}$ Pioneer derivations of the logsum formula were independently developed by Ben-Akiva (1973) and McFadden (1973).
} 
change in the available alternatives - , the expected value of the compensation variation $(\mathrm{CV})$ due to the change in individual $i$ 's utility is expressed as

$$
\begin{aligned}
E_{\epsilon}\left(C V_{i}\right) & =\frac{1}{-\beta_{p}}\left(E_{\epsilon}\left(U_{i}^{\max , a}\right)-E_{\epsilon}\left(U_{i}^{\max , b}\right)\right) \\
& =\frac{1}{-\beta_{p}}\left(\ln \sum_{j=1}^{J} \exp \left(V_{i j}^{a}\right)-\ln \sum_{j=1}^{J} \exp \left(V_{i j}^{b}\right)\right)
\end{aligned}
$$

The marginal willingness to pay (MWTP) can be derive from equation (5) as follows. Assume attribute $q$ changes in a non-marginal fashion across all alternatives -i.e. $q^{a}=q^{b}+\Delta q$ is the level of $q$ after $\Delta q$ has been added to $q^{b}$. Introduce the change in $q$ in equation (5) and, because such a change occurs across all alternatives, factor it ${ }^{8}$. The expected CV can be expressed as follows

$$
E_{\epsilon}\left(C V_{i}[\Delta q]\right)=-\Delta q \frac{\beta_{q}}{\beta_{p}}
$$

where $\beta_{q}$ is the marginal utility from $q$.

Equation (6) reduces to the WTP for a marginal change across alternatives when $\Delta q=1$-i.e. when the change in $q$ is marginal, and

$$
E_{\epsilon}\left(M W T P_{i}\right)=-\frac{\beta_{q}}{\beta_{p}}
$$

Equation (7) can be interpreted as the ratio of the marginal utility from the attribute that changes and the negative of the marginal utility from income.

\subsection{Econometric model}

Empirical estimations of the parameters required in the calculation of the expected MWTP (i.e. $\hat{\beta}_{q}$ and $\hat{\beta}_{p}$ ) can be obtained via a conditional logit econometric specification. The departure point of this empirical model is the same as to establish the theoretical expectations of the welfare measures

\footnotetext{
${ }^{8}$ Further details can be found in Haab and McConnell (2002).
} 
under discrete choice modelling - i.e. $\epsilon_{i j}$ is distributed according to a type I extreme value distribution. Under this assumption, the probability that individual $i$ chooses alternative $j$ is expressed as follows

$$
\begin{aligned}
P_{i j} & =\operatorname{Pr}\left[V_{i j}+\epsilon_{i j}>V_{i k}+\epsilon_{i k} \forall k \neq j\right] \\
& =\operatorname{Pr}\left[\epsilon_{i j}>V_{i k}-V_{i j}+\epsilon_{i k} \forall k \neq j\right] \\
& =\frac{e^{V_{i j}}}{\sum_{k \in J} e^{V_{i k}}}=\frac{e^{\beta^{\prime} x_{i j}}}{\sum_{k \in J} e^{\beta^{\prime} x_{i k}}}
\end{aligned}
$$

A conditional logit (CL) specification faces two limitations to model empirical discrete choice data (Train, 2009). First, a CL can represent systematic variation (i.e. taste variation that is related to observed characteristics) but not random taste variation (i.e. differences in tastes that cannot be linked to observed characteristics). Second, the estimation of the CL probabilities implies proportional substitution across alternatives - more flexible, more realistic patterns cannot be fitted with a CL model. ${ }^{9}$

The random parameters logit (RPL) results from adapting the CL model to incorporate non-systematic heterogeneity in preferences and discard the proportional substitution across alternatives. The RPL turns out to be a highly flexible model that can approximate any random utility model (McFadden and Train, 2000).

The RPL probabilities are the integrals of standard logit probabilities over a density of parameters. That is, keeping in mind equation (8), a RPL is a model whose choice probabilities can be expressed in the following form

$$
P_{i j}=\int \frac{e^{\beta^{\prime} x_{i j}}}{\sum_{k \in J} e^{\beta^{\prime} x_{i k}}} f(\beta) d \beta
$$

where $f(\beta)$ is a density function. The RPL probability is a weighted average of the logit formula evaluated at different values of $\beta$, with the weights given by the density $f(\beta)$. In statistical terms, the weighted average of several

\footnotetext{
${ }^{9} \mathrm{~A}$ third limitation is that a CL is not fitted to capture correlation over time (Train, 2009).
} 
functions is called a mixed function. Consequently, a RPL is a mixture of the logit function evaluated at different $\beta$ 's with $f(\beta)$ as the mixing function.

\section{$5 \quad$ Survey methods and data}

\subsection{Discrete choice experiment}

Table 1 lists the four attributes of our discrete choice experiment (DCE) and their corresponding levels. The included attributes and levels have been chosen closely resembling designs reported in previous studies, and were piloted before embarking on the gathering of final data.

The first attribute refers to the source of renewable energy — solar, biomass, or a 50/50 mix. WTP for residential renewable energy has been documented to vary depending on the source of the renewable energy. In particular, stated WTP is higher for solar and wind energies and lower for biomass and hydropower. These empirical results have been reported both by documents consolidating the relevant literature (Ma et al., 2015; Sundt and Rehdanz, 2015), and by individual studies focusing, for instance, on Spaniard (Gracia et al., 2012), Danish (Yang et al., 2016), American (Borchers et al., 2007), and Italian consumers (Vecchiato and Tempesta, 2015; Cicia et al., 2012).

The second attribute in our DCE refers to the share of renewable energy in current electricity $\operatorname{mix}-10 \%, 20 \%$ or $30 \%$. These values are relevant under the light of the Mexican Energy Transition Law (ETL). Specifically, the ETL mandates that $10.9 \%$ of electricity consumption in Mexico comes from clean energies for large consumers. In addition, $30 \%$ of total electricity generation in Mexico must come from clean energies by 2021.

The inclusion of source as well as share of renewable energy is key for this study's purpose. Respondents may be willing to pay a premium for renewable electricity because they value renewable energies regardless their source. However, it is also possible that this premium arises from respondents' preferences for a specific source of renewable energy. A third alternative is that 
consumers have preferences for a larger share of renewable electricity at the same time that they attach a premium to a specific source. By including both attributes, our DCE is designed to empirically test which one of those three hypotheses holds. Borchers et al. (2007), Gracia et al. (2012), and Yang et al. (2016) are instances of previous studies that also include source and share of renewable energy as attributes in their DCE.

The third attribute in our DCE refers to the number of new jobs created in the renewable sector - which we call green jobs. This attribute takes values $100,1,000$, or 2,000. Strictly speaking, the creation of jobs is not an attribute of the electricity service. This attribute aims to explore whether are altruistic in this respect - i.e. whether respondents' indirect utility is a function of the number of jobs that the renewable sector may create. If respondents' utility positively depends on number of green jobs, then pursuing the adoption of renewable energies may yield a double dividend - generation of less greenhouse emissions per KWh and the creation of jobs that are valued by residential consumers. A new jobs attribute has previously been included in DCE studying stated preferences for residential renewable electricity (e.g. Bergmann et al., 2006; Soliño et al., 2012; Yoo and Ready, 2014).

Similar to Amador et al. (2013), our DCE presents the price attribute as an increase in respondents' self-reported bimonthly electricity bill $-5 \%$, $20 \%$, and $40 \%$. When incorporated in the empirical analysis, we calculate the corresponding hypothetical bimonthly electricity bill by applying the percentage change to the self-reported bill. DCE implicitly implies frames the decision as opting in by including a status quo in the design. Hence, the hypothetical increase in bill can be interpreted as an opt-in extra fee (holding tariffs unchanged) that would compensate for an increase in the share of electricity generated with renewable energies — which we deem more realistic in a context where tariffs are heavily and horizontally subsidized in Mexico.

The scenarios of our DCE were designed according to a orthogonal main 
effects strategy (see Aizaki, 2012). The DCE contains nine choice sets, all of which were presented to respondents. Each choice set includes three alternatives described in terms of four attributes, and a status quo alternative. The respondents were asked to choose one alternative in each choice set. Figure 1 illustrates a choice set.

\subsection{Data collection}

Face-to-face implementation of our DCE was conducted through September to November, 2019. Respondents were approached randomly in public spaces such as shopping malls and the main square in downtown of Aguascalientes city. We made sure that respondents were adults residing in Aguascalientes city that contribute to paying the electricity bill.

\subsection{Descriptive statistics}

Once missing values have been dropped, our sample is composed of 199 respondents. Table 2 reports mean, standard deviation, minimum and maximum of variables describing respondents' and his/her household's characteristics. To put our sample's characteristics in context, table 2 reports in its last column the official statistics for household heads in Aguascalientes (see INEGI, 2018). In comparison to official statistics of household heads in Aguascalientes, our sample is composed by a higher share of females ( $42 \%$ versus $26 \%$ ), and a smaller proportion of married people (44\% versus $58 \%$ ).

In terms of range of age, respondents of our DCE are younger than household heads in Aguascalientes. The proportion of respondents that are younger than 30 years old is higher in our sample (43\% versus $12 \%$ ). The proportion of respondents between 30 and 40 years old in our sample is almost identical to the official proportion of household heads (22\% versus $21 \%$ ). Our sample includes smaller shares of respondents i) between 40 to 50 years old ( $16 \%$ versus $23 \%$ ); ii) between 50 to 60 years old (14\% versus $20 \%$ ); and iii) 
older than 60 years old ( $6 \%$ versus $24 \%$ ).

A bigger proportion of our respondents report higher incomes at the household level in comparison to official statistics at the household head level. While the official proportion for income below 8,000 Mexican pesos (MXP) is $83 \%$, this proportion is $39 \%$ in our sample; for income between MXP 8,000 and MXP 15,000, the official statistic is 10\% and our sample's is 33\%; and for income above MXP 15,000, the official number is $7 \%$ and our sample's is $28 \%$. The proportion of respondents with a full-time jobs is closer to the official statistic for household heads in Aguascalientes - $48 \%$ versus $41 \%$. Around $72 \%$ of our respondents report affording the full amount of the electricity bill —which implies that a share of respondents affording the electricity bill hold part-time jobs.

Two averages at the household level in our sample are almost identical to official numbers. In our sample, around $70 \%$ of respondents live in a house that is owned by a household member and the average number of household members is 3.93. These numbers in the official statistics are $69 \%$ and 3.91 , respectively.

In comparison to the official statistic, a smaller proportion of respondents pay electricity on bimonthly basis $-61 \%$ in our sample versus $89 \%$. The average self-reported electricity bill is MXP 455 - on a bimonthly basis. The average hypothetical bimonthly bill implied by the DCE scenarios is MXP 659. The average self-reported bill is bigger than the official statistic - MXP 455 versus MXP 306-, and a two-tailed t-test rejects the null hypothesis that the difference between these numbers is zero with $99 \%$ of confidence - with a p-value of 0.0019 that corresponds to a t-test statistic of 3.15. We highlight that our sample is similar to official statistics when it comes to household's characteristics such as number of household members and whether the house is owned by a household member.

At the individual level, our sample is composed by a smaller share of married people; and bigger shares of females, and younger respondents who 
belong to higher incomes households. As our respondents of interest are adults that contribute (at least partially) to paying the electricity bill and not necessarily household heads, the differences in individuals' characteristics are not unexpected. The higher self-reported electricity bill and household's income imply that our sample is composed by households richer than the average one in Aguascalientes. In section 8, we discuss implications of these differences in terms of external validity of our results and conclusions.

\section{Results}

\subsection{Econometric specifications}

Table 3 reports estimates from six random parameter logit (RPL) specifications. In all six specifications, normal distributions are assumed for all parameters with exception of the parameter associated to the price attribute which is assumed fixed.

The first specification (I) in table 3 has been estimated on the entire working sample (199 respondents). Considering that 3.93 is the average number of household members, we have re-estimated the RPL on a sample that only includes respondents whose households have less than eight members (195 respondents). This is the second specification (II) reported in table 3. To check the sensitivity of the parameter associated to the price attribute, the third specification (III) excludes 33 choice sets in which the hypothetical bill falls below or above the 1\% tails. The resulting sample contains 195 respondents — which are not the same as in specification (II). The fourth specification in table 3 is estimated on data from 191 respondents that pass (II) + (III) exclusion criteria. The fifth specification (IV) excludes 193 choice sets in which the hypothetical bill falls below or above the $5 \%$ tails, leaving a sample with 177 respondents. The sixth specification is estimated on a sample of 174 respondents resulting from implementing (II)+(IV) exclusion criteria. 
We highlight five features from table 3. First, point estimates of all but the price parameter are similar across specifications. Second, all estimated parameters but the one associated to $20 \%$ of renewable energy are statistically significant. Third, the level of statistical significance of each estimated parameter remains the same across specifications for all attributes - and it is always above a 95\% confidence. Fourth, point estimates of standard deviation of most parameters are similar across specifications - the exceptions being the standard deviations for parameters associated with biomass and 2,000 new green jobs. Fifth, standard deviations associated to status quo, solar, and $30 \%$ of renewable energy are statistically significant across specifications. We deem features 2 and 3 as evidence that all attributes included in our DCE are relevant to respondents; and features 4 and 5, as evidence that unobserved heterogeneity is at place - and RPL should be preferred to conditional logit (CL) specifications.

Features 1 and 4 of table 3 suggest that a few point estimates depend on the composition of the sample under analysis. The price parameter is estimated in a range that goes from -2.46 (first specification in table 3) to -5.59 (sixth specification in table 3) — with standard errors of 0.27 and 0.46 , respectively. Estimates of the standard deviation of the parameter associated to biomass go from a statistically insignificant 0.23 (first specification) to a 0.33 that is significant at $95 \%$ of confidence (sixth specification). Similarly, estimates of the standard deviation of the parameter associate to 2,000 new green jobs go from a statistically insignificant 0.19 to a 0.37 that is significant at $99 \%$ confidence.

The variation in those parameters is associated to the exclusion of (upper and lower) tails of the hypothetical bill's distribution. For the case of the price parameter, point estimates remain similar across specifications on the entire sample and specifications that exclude i) households with more than 8 members; ii) $1 \%$ tails; and iii) these two criteria together. However, a jump from -2.46 (on entire sample) to -5.54 happens when the $5 \%$ tails are 
dropped (fifth specification); and the point estimate becomes -5.59 when the households with more than 8 members are also excluded (sixth specification). Similarly, the standard deviation of the parameter associated to biomass is sensitive to the exclusion of the $5 \%$ tails. The standard deviation of the parameter associated to 2,000 new green jobs is insignificant unless the $1 \%$ tails are excluded and remains significant in specifications that drop the $5 \%$ tails.

When it comes to the sign of specific parameters, we highlight that the negative sign of the status quo parameter implies that respondents dislike the current situation in terms of renewable energies. Taking the solar-biomass mix as reference category, the positive sign of the solar energy parameter implies that solar is preferred over the mix; and the negative sign of the biomass parameter implies that the mix is preferred over biomass - an ordering of preferences consistent with results from previous studies (e.g. Cicia et al., 2012; Gracia et al., 2012; Vecchiato and Tempesta, 2015). Taking 10\% of electricity from renewable sources as reference category, the positive sign of the parameter associated to $30 \%$ from renewable sources implies that a share of $30 \%$ is preferred over a share of $10 \%$. Taking 100 new green jobs as reference category, the positive signs of parameters associated to 1,000 and 2,000 new green jobs, respectively, imply that respondents prefer the creation of 1,000 and 2,000 green jobs over the creation of 100 jobs.

\subsection{Welfare estimates}

For each attribute in our DCE, we have estimated the marginal willingness to pay (MWTP) - expressed as bimonthly, 2018 thousand Mexican pesos (MXP). Table 4 reports six sets of MWTP estimates and their $95 \%$ confidence interval. Each set of MWTP estimates corresponds to one specification in table 3.

We focus our attention on the most conservative welfare estimates -i.e. 
those that imply the smallest MWTP for all attributes. These estimates are reported in the last column of table 4, and arise from the specification that excludes the $5 \%$ tails and the households with more than 8 members. ${ }^{10}$ Thus respondents' loss in utility for remaining in the status quo situation is valued at MXP 899 bimonthly. When it comes to solar energy, respondents' WTP is MXP 34 on a bimonthly basis - a WTP whose 95\% confidence interval includes the zero, and the zero null hypothesis can only be rejected at a $10 \%$ of significance. Respondents report a bimonthly loss of MXP 51 when it comes to biomass energy in comparison to a 50/50 mix of biomass and solar energies. The WTP for a share of $20 \%$ of renewable energy is not statistically significant. In contrast, the WTP for a share of $30 \%$ is MXP 74 on bimonthly basis. The WTP for the creation of 1,000 new green jobs is MXP 40 on bimonthly basis; and MXP 59 for the creation of 2,000 new green jobs.

\subsection{Robustness checks}

We have also estimated conditional logit (CL) specifications on the same six samples than those of the RPL specifications reported in table 3 in the appendix. Parameter estimates from these CL specifications are reported in table A1, and the corresponding MWTP estimates are reported in table A2. Due to limitations of the CL (see section 4), estimates from a CL can only be used to check that the welfare estimates are around the same order of magnitude than those arising from a RPL. Focusing on the last column of table A2, we highlight that most MWTP estimates are similar to those yielded by the RPL specification, with exception of the one associated to the status quo - which the CL yields a third of the value resulting from the RPL. Similarly to welfare estimates from the RPL, table A2 reports a

\footnotetext{
${ }^{10}$ The smaller estimates are direct consequence of the higher absolute value of the price parameter yielded by the corresponding specification. From equation (7), and given the similarity among point estimates of all but the price parameter, it can be seen that a higher absolute value of the price parameter results in a smaller MWTP.
} 
loss in utility from the status quo (value at MXP 298, bimonthly) and from biomass (MXP 46); no statistically significant MWTP for a share of 20\%; and positive MWTP for solar energy (MXP 46), a share of 30\% (MXP 85), and the creation of 1,000 (MXP 31) and 2,000 (MXP 63) new green jobs.

In addition, we have estimated six RPL specifications that assume share of renewable energy and number of new green jobs are continuous variables. The parameter estimates from these RPL and their corresponding welfare estimates are reported in tables A3 and A4, respectively. Focusing our attention on the last column of table A4, we highlight the similarity in point estimates in comparison to those in table 4. For the case of status quo, the loss in utility is estimated at MXP 751 (versus MXP 899 in table 4). For the case of biomass, the loss is valued at MXP 54 (versus MXP 51). MWTP for Solar is MXP 30 (versus MXP 34) —and it is statistically significant only with $p<0.10$. MWTP for a $1 \%$ increase in the share of renewable energy is MXP 5 which implies a WTP of MXP 150 for a share of $30 \%$ which is around twice as much as the MXP 74 reported in table 4. MWTP for an increase in 1,000 new green jobs is MXP 30, or for 2,000 jobs is MXP 60, which are close, respectively to the MXP 40 and MXP 59 reported in table 4.

The corresponding CL specifications and their MWTP estimates are reported in tables A5 and A6. Orders of magnitude and significance levels remain similar to those previously discussed.

\subsection{This paper's results in comparison to those in pre- vious studies}

To put this paper's welfare estimates in context with respect to previous papers' estimates, it is convenient to carry out comparisons in terms of WTP per kWh under specific scenarios. Thus, based on the after-tax self-reported electricity bill, we first retrieve electricity consumption, measured in terms of kWh. In Aguascalientes, consumers face a three-tier block increasing tariff. At the time of the survey, first tier charge was MXP 0.823 to consumption up 
to $150 \mathrm{kWh}$; the second tier charged MXP 0.996 to consumption above 150 $\mathrm{kWh}$ and $\mathrm{u}$ to $280 \mathrm{kWh}$; and the third tier charged 2.912 for consumption over $280 \mathrm{Kwh} .{ }^{11}$ Correspondingly, electricity consumption is inferred by inverting the tariff formula.

Once electricity consumption is inferred, estimated bimonthly WTP is added to the self-reported bimonthly bill, and the total amount is divided by the inferred consumption. This estimation of WTP per kWh assumes that i) consumers know and keep in mind the three-tier block tariff when it comes to deciding electricity consumption; ii) consumers pay attention to beforetax amounts and not to after-tax amounts; and iii) had consumers paid a premium on top of their current bills, they would not change consumption levels.

Table 5 reports WTP per $\mathrm{kWh}$ under nine scenarios that we deem of public policy interest. All nine scenarios assume a 30\% share of renewable energy, and the corresponding WTP is calculated based on MWTP numbers reported in last column of table 4 . A first scenario assumes that this share is achieved with biomass energy (I). Notice that estimation of WTP under this scenario implies the subtraction of MXP 51 from MXP 74 which is the utility that $30 \%$ renewable share produces - the subtraction is due to the desutility from biomass energy in comparison to a 50/50 biomass and solar mix. The second and third scenarios assume (I) and, respectively, the creation of 1,000 and 2,000 new green jobs. The fourth scenario assumes that the $30 \%$ share of renewable energy is reached with solar energy but no premium is paid for this source of energy (II). This no premium assumption aims to take into consideration that, according to estimates in the last column of table 4, MWTP for solar energy is statistically significant only with $p<0.10$. The fifth and sixth scenarios assume (II) and, respectively, the creation of 1,000

\footnotetext{
${ }^{11}$ If annual consumption exceeds $3000 \mathrm{Kwh}$, the household is reclassified as a highconsuming household (Demanda de alto consumo and the corresponding tariff is significantly higher than tier-3 tariff. We are not able to identify any of our respondents in the high-consuming category.
} 
and 2,000 new green jobs. The seventh scenario assumes that the $30 \%$ share of renewable energy is reached with solar energy and a premium of MXP 34 is paid for this source of energy (III). The eight and ninth scenarios assume (III) and, respectively, the creation of 1,000 and 2,000 new green jobs. Table 5 first reports the bimonthly WTP under each of the nine describes scenarios -both in 2018 MXP and USD, respectively. ${ }^{12}$ Then table 5 reports the bimonthly WTP as a proportion of the average bimonthly bill — both selfreported and hypothetical. In its last two columns, table 5 reports bimonthly WTP per kWh —in 2018 MXP and USD (cents), respectively.

A $30 \%$ share of renewable electricity generated through biomass is valued at USD 1.20 on a bimonthly basis. When 1,000 new green jobs are created, consumers' stated benefits are USD 3.28; and when 2,000 new green jobs are added, stated benefits are estimated at USD 4.27. These numbers represent, respectively $5 \%, 14 \%$, and $18 \%$ of the average self-reported bill; or $3 \%, 10 \%$, and $12 \%$ of the hypothetical bill. In terms of USD per $\mathrm{kWh}$, these numbers are equivalent, respectively, to 3.09 cents, 4.33 cents, and 4.93 cents.

For the three scenarios involving solar energy under the assumption that no premium is paid for this energy source, the bimonthly WTP is USD 3.85 for the $30 \%$ share; and USD 5.93 (USD 6.92) when 1,000 (2,000) are added. In temrs of cents per $\mathrm{kWh}$, these numbers translate into 4.68, 5.98, and 6.52, respectively. When a premium for solar energy is added, the bimonthly WTP becomes USD 5.62, USD 7.70, and USD 8.69, respectively. In terms of WTP per $\mathrm{kWh}$, these numbers are equivalent to 5.74, 6.99, and 7.59, respectively.

Our per kWh welfare estimates fall well within the range of values reported by previous studies. The studies summarizing the previous literature provide useful information to carry out a comparison. Ma et al. (2015) find that a majority of WTP values falling between -10 cents and +10 cents and Sundt and Rehdanz (2015) report an average of 3.18 cents. Our lowest per

\footnotetext{
${ }^{12}$ Assuming an exchange rate of $19.22 \mathrm{MXP} / \mathrm{USD}$ which was the average closing price in 2019 according to Macrotrends (2020).
} 
$\mathrm{kWh}$ estimates (3.09) for 30\% share produced with biomass is not only close to the average reported by Sundt and Rehdanz (2015), but also along with our highest bimonthly per kWh estimate (7.59) for 30\% share produced with solar, both fall within the $[-10,+10]$ interval reported by Ma et al. (2015).

In terms of monthly household WTP, our estimates fall well below USD 13.13 (average) and USD 11.67 (median) reported by Sundt and Rehdanz (2015). Our lowest monthly household WTP is equivalent to 0.60 cents, and our highest is USD 4.34. This relative magnitude in the household WTP should not be surprising as most of previous studies have focused on developed countries and Mexico has only recently being classified as upper middle income.

\section{Conclusions and public policy implications}

The national business sector has expressed concerns about the Federal strategy pursuing energy sovereignty due to its negative implications for the competitiveness of the energy sector and potential spillovers to other economic sectors (Gonzalez, 2019; Nava, 2020). This apprehension is shared by international stakeholders and discussions have been hold among diplomats of eight developed countries to explore the best way to communicate such concerns to the Federal administration (Proceso, 2020). Scholars and analysts have also expressed that the planned renovation of state-owned oil and electricity companies may be too costly, and in addition may deviate Mexico from achieving climate change goals (Davis, 2019; Stromsta, 2019; Martin, 2019). These concerns have become stronger as discussions begin on how to overcome the post-coronavirus recession. For instance, the volatility in oil prices make investments in state-owned companies even riskier (CastañedaMorales, 2020; Levy, 2020).

In this context, it is reasonable to highlight the estimations suggesting that Mexico could increase the health of its population and simultaneously 
boost its economy by pursuing a strong climate policy. For instance, Flores et al. (2019) report that Mexico could save more than 25,000 lives and USD 5 billion in public health costs by 2030 if it pursues mitigation of greenhouse emissions - as it has committed under the Paris Agreement. Three-quarters of such reductions would arise from addressing three sectors - electricity, transport and industry.

In a similar vein, findings from this study suggest that a policy simultaneously boosting renewable energies and the creation of green jobs would i) have the support of residential electricity consumers; ii) help in recovering from the post-coronavirus recession; and iii) provide a just transition for workers currently employed in fossil-fuel based industries. A just transition encompasses policies that support workers and families whose jobs, incomes, and livelihoods are at risk as the world pursues sustainable pathways (Rosemberg, 2017).

Our findings suggest that a policy achieving a 30\% share of renewable biomass energy and the creation of 1,000 new green jobs is valued by electricity consumers at USD 3.28 on bimonthly basis - 2.1 of which correspond to the creation of the jobs. To put this number in context, the Federal administration provides USD 195 on a monthly basis to people between 18 and 29 years old who enroll in training programs (STPS, 2020). If the trainee were going to learn skills that facilitate his/her participation in the energy renewable sector, a household in our sample would contribute with around 1\% of the USD 195 that the Federal administration transfer to a trainee. Equivalently, the contribution from 100 households would cover the USD 195 on a bimonthly basis.

A policy encouraging re-training of individuals to transition to the renewable energy industry would also support the recovery from the postcoronavirus recession. As many people is expected to loss their jobs, a compensation during the re-training period would help in avoiding that displaced workers transition to informal sector jobs. A transition to the informal sec- 
tor is undesirable because i) it would decrease wages in the informal sector - negatively impacting not only newcomers but also those who permanently hold an informal job; and ii) it implies a loss in returns from investments that individuals and the State have done on specific skills that are not useful in the informal sector - a waste from which a recovery is difficult once workers transition to the informal sector because it has been documented that they do not return to the formal sector easily (Levy, 2020).

When designing a policy that boosts both renewable energies and creation of green jobs, it is important to keep in mind that the potential number of new jobs differs depending on the source of energy. For instance, International Renewable Energy Agency (2015) estimates that while one Gigawatt (GW) of solar photovoltaic power can create on average 8,250 new jobs, one GW of biomass power can create 31,000 new jobs. Another element to keep in mind is that jobs created by biomass energy generation are mostly permanent jobs but those created by solar energy generation are in general temporary ones.

We want to highlight that the justification of a policy as the one described here does not need to rely on the interpretation of estimated welfare measures as the willingness of consumers to actually pay for the creation of new green jobs or even for an increase in renewable energy share. This clarification is particularly pertinent in times of post-coronavirus recession. There is evidence that, in developed countries, public support of policies encouraging a transition to a renewable energy portfolio has actually translated into the payment of a premium for green electricity (e.g. Knapp et al., 2020). During post-coronavirus recession, however, priorities of residential consumers in Mexico may have changed - at least temporarily - and it may be unrealistic to expect them to monetarily contribute to the creation of green jobs. However, this temporary condition should not take the focus away from mediumand long-term goals such as the reduction of greenhouse emissions and, ultimately, the slow down of climate change. Thus, a just energy transition policy is reasonable not only on the grounds of the stated benefits reported 
in this document but also in terms of wider benefits to the Mexican and international societies.

We also wish to highlight that a policy as the one suggested here can also be designed and implemented by state and municipality administrations. This is a direct consequence of the federal system in Mexico which provides to states and municipalities with a degree of autonomy when it comes to industrial and labor policies.

\section{Limitations and further research}

This paper's findings come with four caveats. A first limitation refers to the external validity. We cannot claim that our results hold for the universe of residential consumers in Aguascalientes City. While we highlight that our sample is similar to official statistics when it comes to households' characteristics such as number of members and whether the house is owned by a household member, we also recognize that at the individual level our sample is composed by a smaller share of married people; and bigger shares of females, younger, and higher incomes respondents. We argue that, because our respondents are adults that contribute (at least partially) to paying the electricity bill, these differences with respect to household heads official statistics should not be surprising. However, this argument does not clarify the external validity of our sample.

The implication is that further research needs to be done to learn whether our results hold at a wider scale. In carrying out future explorations of residential electricity demand, we suggest to keep in mind an issue that will help clarify the representativeness of findings: interviewing official household heads may not provide a clear picture about households' energy-related decisions - Charlier and Martinez-Cruz (2020) argue that there is evidence from both engineering and psychological literatures suggesting that household heads' characteristics and preferences are not necessarily the most im- 
portant ones when it comes to a household's energy consumption and efficiency.

A second caveat refers to the absence in our DCE of attributes that capture potential negative externalities or outcomes arising from the generation of electricity with renewable energy. In some contexts, the environmental benefits associated with transition from fossil fuels to renewable energy sources may have trade-offs in terms of non-negligible negative environmental impacts. Previous DCE studies have documented these trade-offs in the context of landscape impacts, impacts on the fauna and flora, and noise (e.g. Botelho et al., 2018; Kosenius and Ollikainen, 2013). In the Mexican context, Mexico's president has recently emphasized that his administration will prioritize potential environmental damages when granting permits to build energy renewable projects (Infobae, 2020).

The implication from not including trade-offs in terms of environmental externalities is that welfare estimates reported in this study may be smaller once these externalities are incorporated. This paper does not deal with a specific project to which a clear negative externality can be attached. Thus we deem appropriate to abstract from negative externalities in this application.

A few studies have explored consumers preferences in contexts in which higher shares of renewable energies may imply lower-quality services in terms of stability due to the variability in the electricity flow inherent in the renewable energies (Longo et al., 2008; Merk et al., 2019). In this respect, we highlight that the existence of a trade-off between share of renewable energy and stability has recently been challenged by Diesendorf and Elliston (2018). Also for the Mexican case, Vidal-Amaro and Sheinbaum-Pardo (2018) have proposed a transition strategy to a system with a share as high as $75 \%$ of renewable energies in the electricity portfolio. Thus we also deem appropriate to abstract from potential changes in the stability of the services.

A third caveat of this study is the possibility that Mexican residential 
consumers in general, and respondents of our DCE in particular may have changed their priorities due to the coronavirus pandemic. This possibility implies that further research is need on i) whether and the direction to which preferences have shifted; and ii) whether such changes are temporary or permanent. While this study has referred to the Mexican case, it is worth noting that the possibility of a permanent change in societal priorities in terms of renewable energy and climate change policies may have occurred across the world.

A fourth caveat of this study is that, while it documents unobserved heterogeneity in preferences via random parameters logit specifications, it does not explore the factors associated with such heterogeneity. The focus of this paper has been on exploring whether a simultaneous boost of renewable energies and green jobs is justified based on average stated preferences. Future research will focus on documenting whether socioeconomic characteristics, and knowledge and attitudes towards climate change explain the variation in preferences.

\section{Acknowledgments}

This work was supported by the Fondo Sectorial CONACYT-SENER Sustentabilidad Energética [projects No. Cluster Biocombustibles Gaseosos247006 and 245750]. The authors gratefully acknowledge the assistance of Eduardo Robles. 


\section{References}

Aizaki, H. (2012). Basic Functions for Supporting an Implementation of Choice Experiments in R. Journal of Statistical Software 50(c02), 1-24.

Amador, F. J., R. M. González, and F. J. Ramos-Real (2013). Supplier choice and wtp for electricity attributes in an emerging market: The role of perceived past experience, environmental concern and energy saving behavior. Energy Economics 40, 953-966.

Atzmüller, C. and P. M. Steiner (2010). Experimental vignette studies in survey research. Methodology.

Ben-Akiva, M. E. (1973). Structure of passenger travel demand models. Ph. D. thesis, Massachusetts Institute of Technology.

Bergmann, A., N. Hanley, and R. Wright (2006). Valuing the attributes of renewable energy investments. Energy Policy 34(9), 1004-1014.

Borchers, A. M., J. M. Duke, and G. R. Parsons (2007). Does willingness to pay for green energy differ by source? Energy Policy 35(6), 3327-3334.

Botelho, A., L. Lourenço-Gomes, L. M. C. Pinto, S. Sousa, and M. Valente (2018). Discrete-choice experiments valuing local environmental impacts of renewables: Two approaches to a case study in portugal. Environment, Development and Sustainability 20(1), 145-162.

Castañeda-Morales, J. (2020). Frente a la crisis: un golpe de timon. https://nexos.com.mx/?p=47396. Accessed: 2020-04-06.

Charlier, D. and A. Martinez-Cruz (2020). Do habitual energy saving behaviors of household heads impact energy consumption in their own dwelling? An exploration in the french residential sector. Mimeo. 
Cicia, G., L. Cembalo, T. Del Giudice, and A. Palladino (2012). Fossil energy versus nuclear, wind, solar and agricultural biomass: Insights from an Italian national survey. Energy Policy 42, 59-66.

Davis, L. (2019). Mexico goes backward on renewables. https://energyathaas.wordpress.com/2019/08/12/ mexico-goes-backward-on-renewables/. Accessed: 2020-03-10.

Diesendorf, M. and B. Elliston (2018). The feasibility of $100 \%$ renewable electricity systems: A response to critics. Renewable and Sustainable Energy Reviews 93, 318-330.

Flores, A., J. Altamirano, F. Olea, A. Zafra, and J. Rissman (2019). Choosing the Right Path: Low-Cost Policy Options for Enhancing Mexico's Climate Goals While Achieving Long-Term Social Benefits. https://www.wri.org/publication/choosing-right-path. Accessed: 2020-0406.

Gonzalez, S. (2019). Propuestas de CFE afectarían inversiones privadas: Concamin. https://www.jornada.com.mx/ultimas/economia/2019/12/29/propuestasde-cfe-atentan-contra-inversiones-privadas-concamin-3102.html. Accessed: 2020-04-06.

Gracia, A., J. Barreiro-Hurlé, and L. Pérez y Pérez (2012). Can renewable energy be financed with higher electricity prices? Evidence from a Spanish region. Energy Policy 50, 784-794.

Gross, S. (2019). AMLO reverses positive trends in mexico's energy industry. https://www . brookings . edu/blog/order-from-chaos/2019/12/20/ amlo-reverses-positive-trends-in-mexicos-energy-industry/. Accessed: 2020-03-10. 
Haab, T. C. and K. E. McConnell (2002). Valuing environmental and natural resources: the econometrics of non-market valuation. Edward Elgar Publishing.

Hancevic, P., H. Núñez, and J. Rosellón (2019). Tariff schemes and regulations: What changes are needed in the mexican residential electricity sector to support efficient adoption of green technologies? Technical report, IDB Working Paper Series.

Hancevic, P. I., H. M. Nuñez, and J. Rosellon (2017). Distributed photovoltaic power generation: Possibilities, benefits, and challenges for a widespread application in the mexican residential sector. Energy Policy $110,478-489$.

INEGI (2018). Encuesta nacional de ingresos y gastos de los hogares (ENIGH). https://www . inegi .org.mx/programas/enigh/nc/2018/. Accessed: 2020-02-06.

Infobae (2020). AMLO criticó la instalación de aerogeneradores en La Rumorosa porque producen "contaminación visual". https://www.infobae.com/america/mexico/2020/03/29/amlo-criticola-instalacion-de-aerogeneradores-en-la-rumorosa-porque-producencontaminacion-visual/. Accessed: 2020-04-07.

International Renewable Energy Agency (2015). Renewable Energy Prospects: Mexico. Technical report, International Renewable Energy Agency.

IRENA (2018). Power Generation Costs in 2017, Volume Abu Dhabi. International Renewable Energy Agency.

Knapp, L., E. O’Shaughnessy, J. Heeter, S. Mills, and J. M. DeCicco (2020). Will consumers really pay for green electricity? comparing stated and 
revealed preferences for residential programs in the united states. Energy Research E Social Science 65, 101457.

Kosenius, A.-K. and M. Ollikainen (2013). Valuation of environmental and societal trade-offs of renewable energy sources. Energy Policy 62, 11481156.

Levy, S. (2020). Superemos juntos la emergencia. https://www.nexos.com.mx/?p=47405. Accessed: 2020-04-06.

Longo, A., A. Markandya, and M. Petrucci (2008). The internalization of externalities in the production of electricity: Willingness to pay for the attributes of a policy for renewable energy. Ecological Economics 67(1), $140-152$.

Ma, C., A. A. Rogers, M. E. Kragt, F. Zhang, M. Polyakov, F. Gibson, M. Chalak, R. Pandit, and S. Tapsuwan (2015). Consumers' willingness to pay for renewable energy: A meta-regression analysis. Resource and Energy Economics 42, 93-109.

Macrotrends (2020). US Dollar Peso Exchange Rate (USD MXN) -Historical Chart. https://www.macrotrends.net/2559/ us-dollar-mexican-peso-exchange-rate-historical-chart. Accessed: 2020-04-05.

Martin, J. (2019). How AMLO is undermining mexico's clean energy goals. https://www.worldpoliticsreview.com/articles/28370/ how-amlo-is-undermining-mexico-climate-change-goals. Accessed: 2020-03-11.

McFadden, D. (1973). Conditional logit analysis of qualitative choice behavior. Frontiers in Econometrics, 105-142. 
McFadden, D. and K. Train (2000). Mixed mnl models for discrete response. Journal of applied Econometrics 15(5), 447-470.

Merk, C., K. Rehdanz, and C. Schröder (2019). How consumers trade off supply security and green electricity: Evidence from germany and great britain. Energy Economics, 104528.

Méjia, X. and I. E. Saldaña (2019). Energías renovables son demasiado caras: Bartlett. https://www.excelsior.com.mx/nacional/ energias-renovables-son-demasiado-caras-bartlett/1341235. Accessed: 2020-01-28.

Nava, D. (2020). Concamin advierte sobre proyecto de la CRE que busca modificar reglas sobre suministro electrico. https://www.elfinanciero.com.mx/economia/concamin-advierte-sobreproyecto-de-la-cre-que-busca-modificar-reglas-sobre-suministro-electrico. Accessed: 2020-04-06.

Oerlemans, L. A., K.-Y. Chan, and J. Volschenk (2016). Willingness to pay for green electricity: A review of the contingent valuation literature and its sources of error. Renewable and Sustainable Energy Reviews 66, 875-885.

Pokhrel, K. R. (2016). Consumer willingnes to pay for renewable energy: a meta analysis. Master's thesis, Norwegian University of Life Sciences, Ås. Accessed: 2020-03-16.

Proceso (2020). Revelan reunión de diplomáticos de ocho países inquietos por la política energética de AMLO. https://www.proceso.com.mx/621119/politica-energetica-amlo. Accessed: 2020-04-06.

Rehdanz, K., C. Schröder, D. Narita, and T. Okubo (2017). Public preferences for alternative electricity mixes in post-fukushima japan. Energy Economics 65, 262-270. 
Rosemberg, A. (2017). Strengthening just transition policies in international climate governance. https://stanleycenter.org/publications/pab/ RosembergPABStrengtheningJustTransition417.pdf. Accessed: 202003-11.

SENER (2018a). Atlas nacional de zonas con alto potencial de energías limpias. https://dgel.energia.gob.mx/azel/. Accessed: 2019-12-06.

SENER (2018b). Prospectiva de Energias Renovables 2018-2032. Secretaría de Energía.

SENER (2018c). Prospectiva de Gas Natural 2018-2032. Secretaría de Energía.

SENER (2018d). Prospectiva del Sector Electrico 2018-2032. Secretaría de Energía.

SENER (2018e). Reporte de Avance de Energías Limpias Primer Semestre 2018. Secretaría de Energía.

SENER (2019). Programa de Desarrollo del Sistema Eléctrico Nacional 20192033. Secretaría de Energía.

Soliño, M., B. A. Farizo, M. X. Vázquez, and A. Prada (2012). Generating electricity with forest biomass: Consistency and payment timeframe effects in choice experiments. Energy Policy 41, 798-806.

Soon, J.-J. and S.-A. Ahmad (2015). Willingly or grudgingly? a metaanalysis on the willingness-to-pay for renewable energy use. Renewable and Sustainable Energy Reviews 44, 877-887.

STPS (2020). Programa Jovenes Construyendo el Futuro. https://jovenesconstruyendoelfuturo.stps.gob.mx/. Accessed: 202004-06. 
Stromsta, K. (2019). WoodMac: Mexico Set to Miss Clean Energy Target Under AMLO. https://www.greentechmedia.com/articles/read/woodmacmexico-set-to-miss-clean-energy-target-under-amlo. Accessed: 2020-04-06.

Sundt, S. and K. Rehdanz (2015). Consumers' willingness to pay for green electricity: A meta-analysis of the literature. Energy Economics 51, 1-8.

Train, K. E. (2009). Discrete choice methods with simulation. Cambridge university press.

Vecchiato, D. and T. Tempesta (2015). Public preferences for electricity contracts including renewable energy: A marketing analysis with choice experiments. Energy 88, 168-179.

Vidal-Amaro, J. J. and C. Sheinbaum-Pardo (2018). A transition strategy from fossil fuels to renewable energy sources in the mexican electricity system. Journal of Sustainable Development of Energy, Water and Environment Systems 6(1), 47-66.

Yang, Y., H. S. Solgaard, and W. Haider (2016). Wind, hydro or mixed renewable energy source: Preference for electricity products when the share of renewable energy increases. Energy Policy 97, 521-531.

Yoo, J. and R. C. Ready (2014). Preference heterogeneity for renewable energy technology. Energy Economics 42, 101-114. 


\section{Figures}

Your choice

o Alternative A, you would pay $\$ 231$

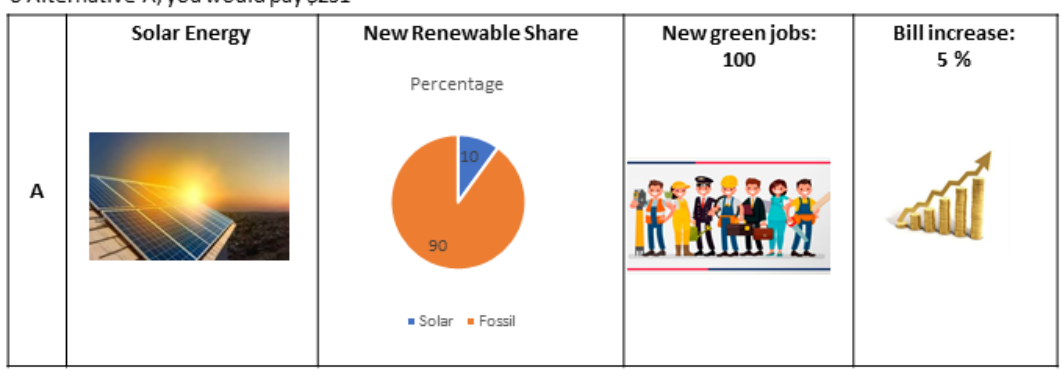



o Alternative C, you would pay $\$ 308$

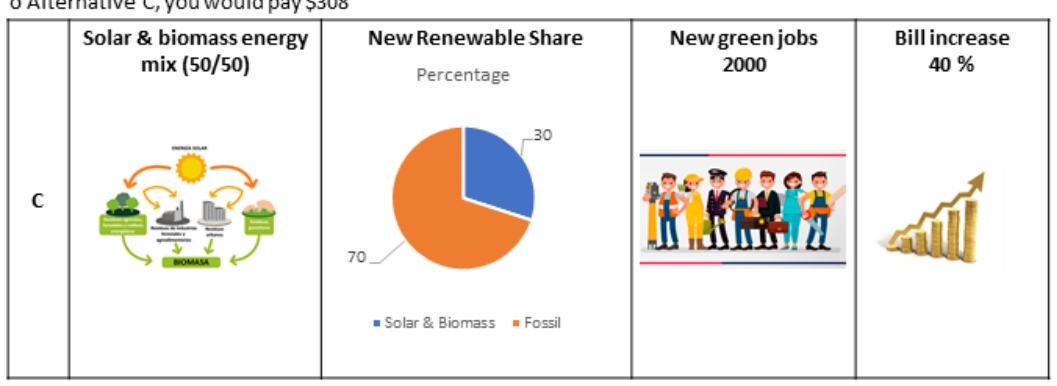

o Alternative D

\begin{tabular}{|l|l|}
\hline D & Status Quo: $94 \%$ of the electricity comes from conventional sources and $6 \%$ from renewable energy
\end{tabular} sources. Bill remains as usual

Figure 1: Example of a choice set 


\section{Tables}

Table 1: Attributes and levels in DCE

\begin{tabular}{ll}
\hline \multicolumn{1}{c}{ Attributes } & \multicolumn{1}{c}{ Levels } \\
\hline Source of renewable energy & Solar, biomass, and mix $(50 / 50)$ \\
$\%$ of renewable energy in current electricity mix & $10 \%, 20 \%$, and $30 \%$ \\
New green jobs (new jobs in renewable energy sector) & $100,1,000$, and 2,000 \\
$\%$ increase in self-reported bimonthly electric bill & $5 \%, 20 \%$, and $40 \%$ \\
\hline
\end{tabular}

Table 2: Sample's summary statistics $(n=199)$, and official statistics for household heads in Aguascalientes

\begin{tabular}{|c|c|c|c|c|c|}
\hline Variable & Mean & Std.Dev. & Min. & Max. & Aguascalientes \\
\hline \multicolumn{6}{|l|}{ Respondent's characteristics } \\
\hline 1 if female & 0.417 & 0.494 & 0.000 & 1.000 & 0.260 \\
\hline 1 if married & 0.442 & 0.498 & 0.000 & 1.000 & 0.580 \\
\hline 1 if younger than 30 years old & 0.427 & 0.496 & 0.000 & 1.000 & 0.120 \\
\hline 1 if 30 to 40 years old & 0.216 & 0.413 & 0.000 & 1.000 & 0.210 \\
\hline 1 if 40 to 50 years old & 0.156 & 0.364 & 0.000 & 1.000 & 0.230 \\
\hline 1 if 50 to 60 years old & 0.136 & 0.343 & 0.000 & 1.000 & 0.200 \\
\hline 1 if older than 60 years old & 0.065 & 0.248 & 0.000 & 1.000 & 0.240 \\
\hline 1 if full-time job & 0.477 & 0.501 & 0.000 & 1.000 & 0.410 \\
\hline 1 if affords full amount of electricity bill & 0.719 & 0.451 & 0.000 & 1.000 & - \\
\hline \multicolumn{6}{|c|}{ Household's characteristics } \\
\hline 1 if monthly income up to $8 \mathrm{~K}$ (MXP) & 0.392 & 0.489 & 0.000 & 1.000 & 0.830 \\
\hline 1 if monthly income between $8 \mathrm{~K}$ and $15 \mathrm{~K}$ (MXP) & 0.332 & 0.472 & 0.000 & 1.000 & 0.100 \\
\hline 1 if monthly income above $15 \mathrm{~K}$ (MXP) & 0.276 & 0.448 & 0.000 & 1.000 & 0.070 \\
\hline 1 if house is owned by a household member & 0.704 & 0.458 & 0.000 & 1.000 & 0.690 \\
\hline Number of household members & 3.930 & 1.890 & 1.000 & 15.000 & 3.910 \\
\hline 1 if bill is paid on bimonthly basis & 0.613 & 0.488 & 0.000 & 1.000 & 0.890 \\
\hline Self-reported electricity bill (thousand MXP) & 0.455 & 0.667 & 0.004 & 7.500 & $0.306^{b}$ \\
\hline Hypothetical bimonthly electricity bill (thousand MXP) & 0.659 & 0.920 & 0.008 & 7.875 & - \\
\hline
\end{tabular}


Table 3: Random Parameter Logit specifications on stated choices

\begin{tabular}{|c|c|c|c|c|c|c|}
\hline & $\begin{array}{l}\text { Entire sample } \\
\text { (l) }\end{array}$ & $\begin{array}{l}\text { Excluding } \\
>8 \text { hh members } \\
\text { (II) }\end{array}$ & $\begin{array}{l}\text { Excluding } \\
1 \% \text { tails }^{d} \\
\text { (III) }\end{array}$ & $(\mathrm{II})+(\mathrm{III})$ & $\begin{array}{l}\text { Excluding } \\
5 \% \text { tails }^{d} \\
\text { (IV) }\end{array}$ & $(\mathrm{II})+(\mathrm{IV})$ \\
\hline $\begin{array}{l}\text { Mean } \\
1 \text { if status quo option }\end{array}$ & $\begin{array}{l}-4.891^{* * *} \\
(0.781)\end{array}$ & $\begin{array}{l}-5.101^{* * *} \\
(0.678)\end{array}$ & $\begin{array}{l}-4.937^{* * *} \\
(0.654)\end{array}$ & $\begin{array}{l}-5.401^{* * *} \\
(0.724)\end{array}$ & $\begin{array}{l}-4.969^{* * *} \\
(0.686)\end{array}$ & $\begin{array}{l}-5.028^{* * *} \\
(0.687)\end{array}$ \\
\hline 1 if solar ${ }^{a}$ & $\begin{array}{l}0.188^{* *} \\
(0.0831)\end{array}$ & $\begin{array}{l}0.204^{* *} \\
(0.0856)\end{array}$ & $\begin{array}{l}0.217^{* *} \\
(0.0851)\end{array}$ & $\begin{array}{l}0.210^{* *} \\
(0.0879)\end{array}$ & $\begin{array}{l}0.206^{* *} \\
(0.0948)\end{array}$ & $\begin{array}{l}0.192^{* *} \\
(0.0955)\end{array}$ \\
\hline 1 if biomass ${ }^{a}$ & $\begin{array}{l}-0.235^{* *} \\
(0.0727)\end{array}$ & $\begin{array}{l}-0.243^{* * *} \\
(0.0714)\end{array}$ & $\begin{array}{l}-0.236^{* *} \\
(0.0732)\end{array}$ & $\begin{array}{l}-0.251^{* * *} \\
(0.0761)\end{array}$ & $\begin{array}{l}-0.269^{* * *} \\
(0.0782)\end{array}$ & $\begin{array}{l}-0.284^{* * *} \\
(0.0818)\end{array}$ \\
\hline $\begin{array}{l}1 \text { if } 20 \% \text { of electricity } \\
\text { comes from renewable sources }\end{array}$ & $\begin{array}{l}-0.0288 \\
(0.0700)\end{array}$ & $\begin{array}{l}-0.0353 \\
(0.0713)\end{array}$ & $\begin{array}{l}-0.0368 \\
(0.0714)\end{array}$ & $\begin{array}{l}-0.0490 \\
(0.0738)\end{array}$ & $\begin{array}{l}-0.0615 \\
(0.0757)\end{array}$ & $\begin{array}{l}-0.0643 \\
(0.0768)\end{array}$ \\
\hline $\begin{array}{l}1 \text { if } 30 \% \text { of electricity } \\
\text { comes from renewable sources }\end{array}$ & $\begin{array}{l}0.407^{* * *} \\
(0.0877)\end{array}$ & $\begin{array}{l}0.423^{* * *} \\
(0.0903)\end{array}$ & $\begin{array}{l}0.413^{* * *} \\
(0.0933)\end{array}$ & $\begin{array}{l}0.417^{* * *} \\
(0.0943)\end{array}$ & $\begin{array}{l}0.425^{* * *} \\
(0.0982)\end{array}$ & $\begin{array}{l}0.413^{* * *} \\
(0.0997)\end{array}$ \\
\hline if 1,000 new green jobs ${ }^{c}$ & $\begin{array}{l}0.196^{* *} \\
(0.0705)\end{array}$ & $\begin{array}{l}0.211^{* *} \\
(0.0712)\end{array}$ & $\begin{array}{l}0.209^{* *} \\
(0.0718)\end{array}$ & $\begin{array}{l}0.226^{* *} \\
(0.0734)\end{array}$ & $\begin{array}{l}0.220^{* *} \\
(0.0770)\end{array}$ & $\begin{array}{l}0.224^{* *} \\
(0.0775)\end{array}$ \\
\hline 1 if 2,000 new green jobs ${ }^{c}$ & $\begin{array}{l}0.308^{* * *} \\
(0.0695)\end{array}$ & $\begin{array}{l}0.313^{* * *} \\
(0.0701)\end{array}$ & $\begin{array}{l}0.328^{* * *} \\
(0.0712)\end{array}$ & $\begin{array}{l}0.335^{* * *} \\
(0.0736)\end{array}$ & $\begin{array}{l}0.353^{* * *} \\
(0.0763)\end{array}$ & $\begin{array}{l}0.329^{* * *} \\
(0.0804)\end{array}$ \\
\hline $\begin{array}{l}\text { Hypothetical bimonthly electricity } \\
\text { bill (thousand MX pesos) }\end{array}$ & $\begin{array}{l}-2.465^{* * *} \\
(0.273)\end{array}$ & $\begin{array}{l}-2.652^{* * *} \\
(0.287)\end{array}$ & $\begin{array}{l}-3.420^{* * *} \\
(0.324)\end{array}$ & $\begin{array}{l}-3.720^{* * *} \\
(0.343)\end{array}$ & $\begin{array}{l}-5.545^{* * *} \\
(0.456)\end{array}$ & $\begin{array}{l}-5.592^{* * *} \\
(0.459)\end{array}$ \\
\hline
\end{tabular}


Table 3: Random Parameter Logit specifications on stated choices

\begin{tabular}{|c|c|c|c|c|c|c|}
\hline & $\begin{array}{l}\text { Entire sample } \\
\text { (1) }\end{array}$ & $\begin{array}{l}\text { Excluding } \\
>8 \text { hh members } \\
\text { (II) }\end{array}$ & $\begin{array}{l}\text { Excluding } \\
1 \% \text { tails }^{d} \\
\text { (III) }\end{array}$ & $(\mathrm{II})+(\mathrm{III})$ & $\begin{array}{l}\text { Excluding } \\
5 \% \text { tails }^{d} \\
(\mathrm{IV})\end{array}$ & $(\mathrm{II})+(\mathrm{IV})$ \\
\hline $\begin{array}{l}\text { SD } \\
1 \text { if status quo option }\end{array}$ & $\begin{array}{l}4.528^{* * *} \\
(0.632)\end{array}$ & $\begin{array}{l}4.093^{* * *} \\
(0.536)\end{array}$ & $\begin{array}{l}4.087^{* * *} \\
(0.489)\end{array}$ & $\begin{array}{l}4.700^{* * *} \\
(0.623)\end{array}$ & $\begin{array}{l}4.827^{* * *} \\
(0.732)\end{array}$ & $\begin{array}{l}5.162^{* * *} \\
(0.614)\end{array}$ \\
\hline 1 if $\operatorname{solar}^{a}$ & $\begin{array}{l}0.715^{* * *} \\
(0.0956)\end{array}$ & $\begin{array}{l}0.743^{* * *} \\
(0.0948)\end{array}$ & $\begin{array}{l}0.734^{* * *} \\
(0.0896)\end{array}$ & $\begin{array}{l}0.779^{* * *} \\
(0.0969)\end{array}$ & $\begin{array}{l}0.843^{* * *} \\
(0.111)\end{array}$ & $\begin{array}{l}0.847^{* * *} \\
(0.106)\end{array}$ \\
\hline 1 if biomass ${ }^{a}$ & $\begin{array}{l}0.237 \\
(0.196)\end{array}$ & $\begin{array}{l}0.116 \\
(0.220)\end{array}$ & $\begin{array}{l}0.150 \\
(0.248)\end{array}$ & $\begin{array}{l}0.288^{* *} \\
(0.137)\end{array}$ & $\begin{array}{l}0.214 \\
(0.230)\end{array}$ & $\begin{array}{l}0.333^{* *} \\
(0.144)\end{array}$ \\
\hline $\begin{array}{l}1 \text { if } 20 \% \text { of electricity } \\
\text { comes from renewable sources }^{b}\end{array}$ & $\begin{array}{l}0.0418 \\
(0.139)\end{array}$ & $\begin{array}{l}0.0995 \\
(0.140)\end{array}$ & $\begin{array}{l}0.0790 \\
(0.130)\end{array}$ & $\begin{array}{l}0.154 \\
(0.128)\end{array}$ & $\begin{array}{l}0.0899 \\
(0.176)\end{array}$ & $\begin{array}{l}0.0645 \\
(0.158)\end{array}$ \\
\hline $\begin{array}{l}1 \text { if } 30 \% \text { of electricity } \\
\text { comes from renewable sources }^{b}\end{array}$ & $\begin{array}{l}0.829^{* * *} \\
(0.0982)\end{array}$ & $\begin{array}{l}0.867^{* * *} \\
(0.101)\end{array}$ & $\begin{array}{l}0.906^{* * *} \\
(0.103)\end{array}$ & $\begin{array}{l}0.940^{* * *} \\
(0.104)\end{array}$ & $\begin{array}{l}0.947^{* * *} \\
(0.107)\end{array}$ & $\begin{array}{l}0.951^{* * *} \\
(0.110)\end{array}$ \\
\hline 1 if 1,000 new green jobs ${ }^{c}$ & $\begin{array}{l}0.0577 \\
(0.0991)\end{array}$ & $\begin{array}{l}0.0127 \\
(0.107)\end{array}$ & $\begin{array}{l}0.0420 \\
(0.107)\end{array}$ & $\begin{array}{l}0.0620 \\
(0.118)\end{array}$ & $\begin{array}{l}0.0899 \\
(0.114)\end{array}$ & $\begin{array}{l}0.0150 \\
(0.112)\end{array}$ \\
\hline 1 if 2,000 new green jobs ${ }^{c}$ & $\begin{array}{l}0.195 \\
(0.130)\end{array}$ & $\begin{array}{l}0.163 \\
(0.147)\end{array}$ & $\begin{array}{l}0.228^{*} \\
(0.127)\end{array}$ & $\begin{array}{l}0.275^{* *} \\
(0.130)\end{array}$ & $\begin{array}{l}0.256^{*} \\
(0.144)\end{array}$ & $\begin{array}{l}0.371^{* * *} \\
(0.104)\end{array}$ \\
\hline Respondents & 199 & 195 & 195 & 191 & 177 & 174 \\
\hline Observations & 7164 & 7020 & 7032 & 6888 & 6390 & 6287 \\
\hline 11 & -1928.4 & -1873.1 & -1865.4 & -1811.6 & -1679.1 & -1644.1 \\
\hline $\mathrm{AIC}$ & 3886.8 & 3776.2 & 3760.8 & 3653.3 & 3388.2 & 3318.1 \\
\hline
\end{tabular}


Table 3: Random Parameter Logit specifications on stated choices

\begin{tabular}{llllc}
\hline & $\begin{array}{l}\text { Entire sample } \\
(\mathrm{l})\end{array}$ & $\begin{array}{l}\text { Excluding } \\
>8 \text { hh members } \\
(\mathrm{II})\end{array}$ & $\begin{array}{l}\text { Excluding } \\
1 \% \text { tails }^{d}\end{array}$ & $\begin{array}{l}\text { Excluding } \\
(\mathrm{III})\end{array}$ \\
\hline $\mathrm{BIC}$ & 3989.9 & 3879.1 & 3863.7 & 3755.8 \\
\hline
\end{tabular}

Standard errors in parentheses. ${ }^{*} p<0.10,{ }^{* *} p<0.05,{ }^{* * *} p<0.001$.

${ }^{a}$ Reference category: 50/50 combination of solar and biomass.

${ }^{b}$ Reference category: $10 \%$ of electricity comes from renewable sources.

${ }^{c}$ Reference category: 100 new green jobs.

${ }^{d}$ It refers to both lower and upper tails of the distribution of hypothetical bimonthly electricity bill. 
Table 4: Marginal willingness to pay (bimonthly, 2018 thousand Mexican pesos) and 95\% confidence intervals resulting from Random Parameter Logit specifications reported in table 3

\begin{tabular}{|c|c|c|c|c|c|c|}
\hline MWTP for & $\begin{array}{l}\text { Entire sample } \\
\text { (I) }\end{array}$ & $\begin{array}{c}\text { Excluding } \\
>8 \text { hh members } \\
\text { (II) }\end{array}$ & $\begin{array}{l}\text { Excluding } \\
1 \% \text { tails } \\
\text { (III) }\end{array}$ & $(\mathrm{II})+(\mathrm{III})$ & $\begin{array}{l}\text { Excluding } \\
5 \% \text { tails } \\
\text { (IV) }\end{array}$ & $(\mathrm{II})+(\mathrm{IV})$ \\
\hline Status quo & -1.984 & -1.923 & -1.443 & -1.452 & -0.896 & -0.899 \\
\hline Lower Bound & -2.904 & -2.687 & -1.979 & -1.973 & -1.212 & -1.208 \\
\hline Upper Bound & -1.271 & -1.342 & -1.007 & -1.016 & -0.625 & -0.633 \\
\hline Solar & 0.076 & 0.077 & 0.063 & 0.056 & 0.037 & $0.034^{a}$ \\
\hline Lower Bound & 0.007 & 0.011 & 0.013 & 0.009 & 0.003 & 0.000 \\
\hline Upper Bound & 0.150 & 0.147 & 0.117 & 0.106 & 0.072 & 0.069 \\
\hline Biomass & -0.095 & -0.091 & -0.069 & -0.068 & -0.049 & -0.051 \\
\hline Lower Bound & -0.157 & -0.148 & -0.112 & -0.109 & -0.077 & -0.080 \\
\hline Upper Bound & -0.042 & -0.043 & -0.030 & -0.030 & -0.023 & -0.024 \\
\hline $20 \%$ of renewable energy & -0.012 & -0.013 & -0.011 & -0.013 & -0.011 & -0.011 \\
\hline Lower Bound & -0.068 & -0.066 & -0.052 & -0.052 & -0.038 & -0.038 \\
\hline Upper Bound & 0.048 & 0.043 & 0.033 & 0.028 & 0.017 & 0.017 \\
\hline $30 \%$ of renewable energy & 0.165 & 0.159 & 0.121 & 0.112 & 0.077 & 0.074 \\
\hline Lower Bound & 0.097 & 0.095 & 0.069 & 0.065 & 0.044 & 0.040 \\
\hline Upper Bound & 0.254 & 0.243 & 0.182 & 0.169 & 0.116 & 0.114 \\
\hline 1,000 new green jobs & 0.080 & 0.080 & 0.061 & 0.061 & 0.040 & 0.040 \\
\hline Lower Bound & 0.024 & 0.028 & 0.021 & 0.023 & 0.013 & 0.013 \\
\hline Upper Bound & 0.144 & 0.140 & 0.107 & 0.104 & 0.069 & 0.069 \\
\hline 2,000 new green jobs & 0.125 & 0.118 & 0.096 & 0.090 & 0.064 & 0.059 \\
\hline Lower Bound & 0.068 & 0.065 & 0.055 & 0.051 & 0.037 & 0.030 \\
\hline Upper Bound & 0.199 & 0.186 & 0.145 & 0.137 & 0.096 & 0.092 \\
\hline
\end{tabular}

${ }^{a}$ Zero null hypothesis can be rejected with $p<0.10$. 
Table 5: Bimonthly willingness to pay for renewable energy share/renewable source/green jobs scenarios — calculated based on estimates reported in last column of table 4

\begin{tabular}{|c|c|c|c|c|c|c|}
\hline \multirow[b]{3}{*}{ Scenarios } & \multicolumn{4}{|c|}{$\begin{array}{l}\text { As proportion of } \\
\text { average bimonthly bill }\end{array}$} & \multirow{2}{*}{\multicolumn{2}{|c|}{ per $\mathrm{kWh}^{b}$}} \\
\hline & \multicolumn{2}{|c|}{ Bimonthly WTP } & \multirow{2}{*}{$\begin{array}{l}\text { self-reported } \\
(\text { MXP 455) }\end{array}$} & \multirow{2}{*}{$\begin{array}{l}\text { hypothetical } \\
\text { (MXP 659) }\end{array}$} & & \\
\hline & (2018 MXP) & $\mathrm{USD}^{a}$ & & & (2018 MXP) & $\mathrm{USD}(\text { cents })^{a}$ \\
\hline \multicolumn{7}{|c|}{ Assuming desutility of $51 \mathrm{MXP}$ from biomass } \\
\hline $30 \%$ share from biomass (I) & 23 & 1.20 & 0.05 & 0.03 & 0.59 & 3.09 \\
\hline (I) $+1,000$ new green jobs & 63 & 3.28 & 0.14 & 0.10 & 0.83 & 4.33 \\
\hline (I) $+2,000$ new green jobs & 82 & 4.27 & 0.18 & 0.12 & 0.95 & 4.93 \\
\hline \multicolumn{7}{|c|}{ Assuming no premium for solar } \\
\hline $30 \%$ share from solar $(\mathrm{II})$ & 74 & 3.85 & 0.16 & 0.11 & 0.90 & 4.68 \\
\hline (II) $+1,000$ new green jobs & 114 & 5.93 & 0.25 & 0.17 & 1.14 & 5.93 \\
\hline (II) $+2,000$ new green jobs & 133 & 6.92 & 0.29 & 0.20 & 1.25 & 6.52 \\
\hline \multicolumn{7}{|c|}{ Assuming a 34 MXP premium for solar } \\
\hline $30 \%$ share from solar (III) & 108 & 5.62 & 0.24 & 0.16 & 1.10 & 5.74 \\
\hline$(\mathrm{III})+1,000$ new green jobs & 148 & 7.70 & 0.33 & 0.22 & 1.34 & 6.99 \\
\hline (III) $+2,000$ new green jobs & 167 & 8.69 & 0.37 & 0.25 & 1.46 & 7.59 \\
\hline
\end{tabular}

\footnotetext{
${ }^{a}$ Assuming an exchange rate of 19.22 MXP/USD which was the average closing price in 2019 (see Macrotrends, 2020).

${ }^{b}$ Sample mean of implied bimonthly WTP per $\mathrm{kWh}$, assuming consumed $\mathrm{kWh}$ remain unchanged if an scenario is in place. As described in section 6.4, based on after-tax self-reported bill, i) consumers are first assigned to their corresponding tariff; ii) consumed kWh are inferred; iii) for a given scenario, bimonthly WTP (first column in table 5) is added to the self-reported bill; and iv) assuming that $\mathrm{kWh}$ remain unchanged, MXP per KWh are calculated under each scenario.
} 
Appendix 
Table A1: Conditional Logit specifications on stated choices

\begin{tabular}{|c|c|c|c|c|c|c|}
\hline & $\begin{array}{l}\text { Entire sample } \\
\text { (I) }\end{array}$ & $\begin{array}{c}\text { Excluding } \\
>8 \text { hh members } \\
\text { (II) }\end{array}$ & $\begin{array}{l}\text { Excluding } \\
1 \% \text { tails }^{d} \\
\quad \text { (III) }\end{array}$ & $(\mathrm{II})+(\mathrm{III})$ & $\begin{array}{l}\text { Excluding } \\
5 \% \text { tails }^{d} \\
\quad(\mathrm{IV})\end{array}$ & $(\mathrm{II})+(\mathrm{IV})$ \\
\hline 1 if status quo option & $\begin{array}{c}-1.211^{* * *} \\
(0.111)\end{array}$ & $\begin{array}{c}-1.244^{* * *} \\
(0.112)\end{array}$ & $\begin{array}{l}-1.268^{* * *} \\
(0.112)\end{array}$ & $\begin{array}{c}-1.307^{* * *} \\
(0.114)\end{array}$ & $\begin{array}{l}-1.373^{* * *} \\
(0.118)\end{array}$ & $\begin{array}{c}-1.403^{* * *} \\
(0.119)\end{array}$ \\
\hline 1 if solar ${ }^{a}$ & $\begin{array}{l}0.230^{* * *} \\
(0.0607)\end{array}$ & $\begin{array}{l}0.223^{* * *} \\
(0.0613)\end{array}$ & $\begin{array}{l}0.238^{* * *} \\
(0.0616)\end{array}$ & $\begin{array}{l}0.232^{* * *} \\
(0.0623)\end{array}$ & $\begin{array}{l}0.229^{* * *} \\
(0.0646)\end{array}$ & $\begin{array}{l}0.217^{* * *} \\
(0.0652)\end{array}$ \\
\hline 1 if biomass ${ }^{a}$ & $\begin{array}{l}-0.196^{* *} \\
(0.0669)\end{array}$ & $\begin{array}{l}-0.203^{* *} \\
(0.0676)\end{array}$ & $\begin{array}{l}-0.192^{* *} \\
(0.0678)\end{array}$ & $\begin{array}{l}-0.199^{* *} \\
(0.0686)\end{array}$ & $\begin{array}{l}-0.214^{* *} \\
(0.0712)\end{array}$ & $\begin{array}{l}-0.218^{* *} \\
(0.0717)\end{array}$ \\
\hline $\begin{array}{l}1 \text { if } 20 \% \text { of electricity comes } \\
\text { comes from renewable sources }^{b}\end{array}$ & $\begin{array}{l}-0.0405 \\
(0.0677)\end{array}$ & $\begin{array}{l}-0.0488 \\
(0.0684)\end{array}$ & $\begin{array}{l}-0.0532 \\
(0.0686)\end{array}$ & $\begin{array}{l}-0.0620 \\
(0.0694)\end{array}$ & $\begin{array}{l}-0.0789 \\
(0.0719)\end{array}$ & $\begin{array}{l}-0.0826 \\
(0.0726)\end{array}$ \\
\hline $\begin{array}{l}1 \text { if } 30 \% \text { of electricity } \\
\text { comes from renewable sources }^{b}\end{array}$ & $\begin{array}{l}0.409^{* * *} \\
(0.0612)\end{array}$ & $\begin{array}{l}0.406^{* * *} \\
(0.0618)\end{array}$ & $\begin{array}{l}0.414^{* * *} \\
(0.0620)\end{array}$ & $\begin{array}{l}0.411^{\text {*** }} \\
(0.0627)\end{array}$ & $\begin{array}{c}0.392^{* * *} \\
(0.0651)\end{array}$ & $\begin{array}{l}0.400^{* * *} \\
(0.0656)\end{array}$ \\
\hline 1 if 1,000 new green jobs ${ }^{c}$ & $\begin{array}{c}0.137^{* *} \\
(0.0657)\end{array}$ & $\begin{array}{c}0.145^{* *} \\
(0.0664)\end{array}$ & $\begin{array}{c}0.138^{* *} \\
(0.0667)\end{array}$ & $\begin{array}{c}0.147^{* *} \\
(0.0674)\end{array}$ & $\begin{array}{c}0.140^{* *} \\
(0.0702)\end{array}$ & $\begin{array}{c}0.145^{* *} \\
(0.0707)\end{array}$ \\
\hline 1 if 2,000 new green jobs ${ }^{c}$ & $\begin{array}{l}0.269^{* * *} \\
(0.0636)\end{array}$ & $\begin{array}{l}0.270^{* * *} \\
(0.0643)\end{array}$ & $\begin{array}{l}0.278^{* * *} \\
(0.0645)\end{array}$ & $\begin{array}{l}0.280^{* * *} \\
(0.0653)\end{array}$ & $\begin{array}{l}0.300^{* * *} \\
(0.0677)\end{array}$ & $\begin{array}{l}0.294^{* * *} \\
(0.0683)\end{array}$ \\
\hline $\begin{array}{l}\text { Hypothetical bimonthly electricity } \\
\text { bill (thousand MX pesos) }\end{array}$ & $\begin{array}{c}-2.178^{* * *} \\
(0.241)\end{array}$ & $\begin{array}{c}-2.309^{* * *} \\
(0.250)\end{array}$ & $\begin{array}{c}-3.024^{* * *} \\
(0.285)\end{array}$ & $\begin{array}{c}-3.243^{* * *} \\
(0.298)\end{array}$ & $\begin{array}{c}-4.706^{* * *} \\
(0.395)\end{array}$ & $\begin{array}{c}-4.708^{* * *} \\
(0.395)\end{array}$ \\
\hline Respondents & 199 & 195 & 195 & 191 & 177 & 174 \\
\hline Observations & 7164 & 7020 & 7032 & 6888 & 6390 & 6287 \\
\hline ll & -2203.3 & -2152.2 & -2146.1 & -2093.0 & -1939.7 & -1902.6 \\
\hline AIC & 4422.5 & 4320.5 & 4308.3 & 4202.1 & 3895.4 & 3821.3 \\
\hline $\mathrm{BIC}$ & 4477.6 & 4375.3 & 4363.1 & 4256.8 & 3949.5 & 3875.3 \\
\hline
\end{tabular}

Standard errors in parentheses. ${ }^{*} p<0.10,{ }^{* *} p<0.05,{ }^{* * *} p<0.001$.

${ }^{a}$ Reference category: 50/50 combination of solar and biomass.

${ }^{b}$ Reference category: $10 \%$ of electricity comes from renewable sources.

${ }^{c}$ Reference category: 100 new green jobs.

${ }^{d}$ It refers to both lower and upper tails of the distribution of hypothetical bimonthly electricity bill. 
Table A2: Marginal willingness to pay (bimonthly, 2018 thousand Mexican pesos) and 95\% confidence intervals resulting from Conditional Logit specifications reported in table A1

\begin{tabular}{|c|c|c|c|c|c|c|}
\hline MWTP for & $\begin{array}{l}\text { Entire sample } \\
\text { (I) }\end{array}$ & $\begin{array}{c}\text { Excluding } \\
>8 \text { hh members } \\
(\mathrm{II})\end{array}$ & $\begin{array}{l}\text { Excluding } \\
1 \% \text { tails } \\
\text { (III) }\end{array}$ & $(\mathrm{II})+(\mathrm{III})$ & $\begin{array}{l}\text { Excluding } \\
5 \% \text { tails } \\
\text { (IV) }\end{array}$ & $(\mathrm{II})+(\mathrm{IV})$ \\
\hline Status quo & -0.556 & -0.539 & -0.419 & -0.403 & -0.292 & -0.298 \\
\hline Lower Bound & -0.722 & -0.695 & -0.529 & -0.506 & -0.360 & -0.368 \\
\hline Upper Bound & -0.436 & -0.424 & -0.335 & -0.324 & -0.236 & -0.241 \\
\hline Solar & 0.106 & 0.097 & 0.079 & 0.071 & 0.049 & 0.046 \\
\hline Lower Bound & 0.049 & 0.043 & 0.037 & 0.033 & 0.021 & 0.018 \\
\hline Upper Bound & 0.171 & 0.159 & 0.125 & 0.116 & 0.079 & 0.077 \\
\hline Biomass & -0.090 & -0.088 & -0.064 & -0.061 & -0.045 & -0.046 \\
\hline Lower Bound & -0.157 & -0.151 & -0.110 & -0.105 & -0.076 & -0.077 \\
\hline Upper Bound & -0.035 & -0.035 & -0.023 & -0.024 & -0.018 & -0.019 \\
\hline $20 \%$ of renewable energy & -0.019 & -0.021 & -0.018 & -0.019 & -0.017 & -0.018 \\
\hline Lower Bound & -0.083 & -0.083 & -0.064 & -0.063 & -0.048 & -0.049 \\
\hline Upper Bound & 0.047 & 0.041 & 0.030 & 0.025 & 0.014 & 0.014 \\
\hline $30 \%$ of renewable energy & 0.188 & 0.176 & 0.137 & 0.127 & 0.083 & 0.085 \\
\hline Lower Bound & 0.129 & 0.120 & 0.095 & 0.088 & 0.057 & 0.058 \\
\hline Upper Bound & 0.268 & 0.251 & 0.191 & 0.177 & 0.117 & 0.119 \\
\hline 1,000 new green jobs & 0.063 & 0.063 & 0.046 & 0.045 & 0.030 & 0.031 \\
\hline Lower Bound & 0.004 & 0.006 & 0.002 & 0.004 & 0.000 & 0.001 \\
\hline Upper Bound & 0.128 & 0.125 & 0.092 & 0.089 & 0.060 & 0.062 \\
\hline 2,000 new green jobs & 0.124 & 0.117 & 0.092 & 0.086 & 0.064 & 0.063 \\
\hline Lower Bound & 0.066 & 0.063 & 0.051 & 0.047 & 0.036 & 0.035 \\
\hline Upper Bound & 0.197 & 0.187 & 0.144 & 0.136 & 0.098 & 0.097 \\
\hline
\end{tabular}


Table A3: Random Parameter Logit specifications on stated choices —assuming that \% of renewable energy and new green jobs attributes are continuous

\begin{tabular}{|c|c|c|c|c|c|c|}
\hline & $\begin{array}{l}\text { Entire sample } \\
\text { (l) }\end{array}$ & $\begin{array}{l}\text { Excluding } \\
>8 \text { hh members } \\
\text { (II) }\end{array}$ & $\begin{array}{l}\text { Excluding } \\
1 \% \text { tails }^{d} \\
\text { (III) }\end{array}$ & $(\mathrm{II})+(\mathrm{III})$ & $\begin{array}{l}\text { Excluding } \\
5 \% \text { tails }^{d} \\
\text { (IV) }\end{array}$ & $(\mathrm{II})+(\mathrm{IV})$ \\
\hline $\begin{array}{l}\text { Mean } \\
1 \text { if status quo option }\end{array}$ & $\begin{array}{l}-4.348^{* * *} \\
(0.638)\end{array}$ & $\begin{array}{l}-4.603^{* * *} \\
(0.653)\end{array}$ & $\begin{array}{l}-4.801^{* * *} \\
(0.681)\end{array}$ & $\begin{array}{l}-4.192^{* * *} \\
(0.677)\end{array}$ & $\begin{array}{l}-4.777^{* * *} \\
(0.712)\end{array}$ & $\begin{array}{l}-4.595^{* * *} \\
(0.600)\end{array}$ \\
\hline 1 if solar $^{a}$ & $\begin{array}{l}0.173^{* *} \\
(0.0822)\end{array}$ & $\begin{array}{l}0.190^{* *} \\
(0.0846)\end{array}$ & $\begin{array}{l}0.215^{* *} \\
(0.0849)\end{array}$ & $\begin{array}{l}0.198^{* *} \\
(0.0861)\end{array}$ & $\begin{array}{l}0.198^{* *} \\
(0.0928)\end{array}$ & $\begin{array}{l}0.140 \\
(0.0998)\end{array}$ \\
\hline 1 if biomass ${ }^{a}$ & $\begin{array}{l}-0.234^{* *} \\
(0.0724)\end{array}$ & $\begin{array}{l}-0.239^{* * *} \\
(0.0719)\end{array}$ & $\begin{array}{l}-0.233^{* *} \\
(0.0733)\end{array}$ & $\begin{array}{l}-0.240^{* * *} \\
(0.0728)\end{array}$ & $\begin{array}{l}-0.271^{* * *} \\
(0.0806)\end{array}$ & $\begin{array}{l}-0.278^{* * *} \\
(0.0832)\end{array}$ \\
\hline$\%$ of renewable energy ${ }^{b}$ & $\begin{array}{l}0.0242^{* * *} \\
(0.00503)\end{array}$ & $\begin{array}{l}0.0238^{* * *} \\
(0.00524)\end{array}$ & $\begin{array}{l}0.0246^{* * *} \\
(0.00531)\end{array}$ & $\begin{array}{l}0.0243^{* * *} \\
(0.00544)\end{array}$ & $\begin{array}{l}0.0254^{* * *} \\
(0.00568)\end{array}$ & $\begin{array}{l}0.0229^{* * *} \\
(0.00625)\end{array}$ \\
\hline New green jobs (thousands) ${ }^{c}$ & $\begin{array}{l}0.147^{* * *} \\
(0.0365)\end{array}$ & $\begin{array}{l}0.152^{* * *} \\
(0.0366)\end{array}$ & $\begin{array}{l}0.158^{* * *} \\
(0.0371)\end{array}$ & $\begin{array}{l}0.159^{* * *} \\
(0.0376)\end{array}$ & $\begin{array}{l}0.174^{* * *} \\
(0.0389)\end{array}$ & $\begin{array}{l}0.183^{* * *} \\
(0.0439)\end{array}$ \\
\hline $\begin{array}{l}\text { Hypothetical bimonthly electricity } \\
\text { bill (thousand MX pesos) }\end{array}$ & $\begin{array}{l}-2.544^{* * *} \\
(0.279)\end{array}$ & $\begin{array}{l}-2.618^{* * *} \\
(0.286)\end{array}$ & $\begin{array}{l}-3.458^{* * *} \\
(0.326)\end{array}$ & $\begin{array}{l}-3.652^{* * *} \\
(0.342)\end{array}$ & $\begin{array}{l}-5.537^{* * *} \\
(0.458)\end{array}$ & $\begin{array}{l}-5.699^{* * *} \\
(0.465)\end{array}$ \\
\hline $\begin{array}{l}\text { SD } \\
1 \text { if status quo option }\end{array}$ & $\begin{array}{l}3.731^{* * *} \\
(0.475)\end{array}$ & $\begin{array}{l}4.457^{* * *} \\
(0.506)\end{array}$ & $\begin{array}{l}4.179^{* * *} \\
(0.470)\end{array}$ & $\begin{array}{l}4.108^{* * *} \\
(0.490)\end{array}$ & $\begin{array}{l}3.932^{* * *} \\
(0.574)\end{array}$ & $\begin{array}{l}3.855^{* * *} \\
(0.398)\end{array}$ \\
\hline 1 if solar $^{a}$ & $0.702^{* * *}$ & $0.743^{* * *}$ & $0.751^{* * *}$ & $0.759^{* * *}$ & $0.824^{* * *}$ & $0.876^{* * *}$ \\
\hline
\end{tabular}


Table A3: Random Parameter Logit specifications on stated choices —assuming that \% of renewable energy and new green jobs attributes are continuous

\begin{tabular}{|c|c|c|c|c|c|c|}
\hline & $\begin{array}{l}\text { Entire sample } \\
\text { (l) }\end{array}$ & $\begin{array}{l}\text { Excluding } \\
>8 \text { hh members } \\
\text { (II) }\end{array}$ & $\begin{array}{l}\text { Excluding } \\
1 \% \text { tails }^{d} \\
\text { (III) }\end{array}$ & $(\mathrm{II})+(\mathrm{III})$ & $\begin{array}{l}\text { Excluding } \\
5 \% \text { tails }^{d} \\
\text { (IV) }\end{array}$ & $(\mathrm{II})+(\mathrm{IV})$ \\
\hline & $(0.0875)$ & $(0.0954)$ & $(0.0950)$ & $(0.0958)$ & $(0.103)$ & $(0.0999)$ \\
\hline 1 if biomass $^{a}$ & $\begin{array}{l}0.245 \\
(0.153)\end{array}$ & $\begin{array}{l}0.191 \\
(0.196)\end{array}$ & $\begin{array}{l}0.225 \\
(0.193)\end{array}$ & $\begin{array}{l}0.143 \\
(0.182)\end{array}$ & $\begin{array}{l}0.287 \\
(0.201)\end{array}$ & $\begin{array}{l}0.172 \\
(0.309)\end{array}$ \\
\hline$\%$ of renewable energy ${ }^{b}$ & $\begin{array}{l}0.0522^{* * *} \\
(0.00589)\end{array}$ & $\begin{array}{l}0.0551^{* * *} \\
(0.00647)\end{array}$ & $\begin{array}{l}0.0578^{* * *} \\
(0.00656)\end{array}$ & $\begin{array}{l}0.0576^{* * *} \\
(0.00713)\end{array}$ & $\begin{array}{l}0.0564^{* * *} \\
(0.00608)\end{array}$ & $\begin{array}{l}0.0663^{* * *} \\
(0.00705)\end{array}$ \\
\hline New green jobs (thousands) ${ }^{c}$ & $\begin{array}{l}0.121 \\
(0.0866)\end{array}$ & $\begin{array}{l}0.0766 \\
(0.140) \\
\end{array}$ & $\begin{array}{l}0.113 \\
(0.0989) \\
\end{array}$ & $\begin{array}{l}0.117 \\
(0.106) \\
\end{array}$ & $\begin{array}{l}0.0867 \\
(0.201) \\
\end{array}$ & $\begin{array}{l}0.256^{* * *} \\
(0.0700)\end{array}$ \\
\hline Respondents & 199 & 195 & 195 & 191 & 177 & 174 \\
\hline Observations & 7164 & 7020 & 7032 & 6888 & 6390 & 6287 \\
\hline 11 & -1930.2 & -1881.8 & -1872.3 & -1826.5 & -1691.4 & -1647.9 \\
\hline $\mathrm{AIC}$ & 3882.3 & 3785.5 & 3766.5 & 3675.0 & 3404.9 & 3317.8 \\
\hline $\mathrm{BIC}$ & 3958.0 & 3861.0 & 3842.0 & 3750.2 & 3479.2 & 3392.0 \\
\hline
\end{tabular}

Standard errors in parentheses. ${ }^{*} p<0.10,{ }^{* *} p<0.05,{ }^{* * *} p<0.001$.

${ }^{a}$ Reference category: 50/50 combination of solar and biomass.

$b \%$ of renewable energy is assumed a continuous variable in specifications reported in table A3.

${ }^{c}$ New green jobs is assumed a continuous variable in specifications reported in table A3.

${ }^{d}$ It refers to both lower and upper tails of the distribution of hypothetical bimonthly electricity bill. 
Table A4: Marginal willingness to pay (bimonthly, 2018 thousand Mexican pesos) and 95\% confidence intervals resulting from Random Parameter Logit specifications reported in table A3

\begin{tabular}{|c|c|c|c|c|c|c|}
\hline MWTP for & $\begin{array}{l}\text { Entire sample } \\
\text { (I) }\end{array}$ & $\begin{array}{c}\text { Excluding } \\
>8 \text { hh members } \\
\text { (II) }\end{array}$ & $\begin{array}{l}\text { Excluding } \\
1 \% \text { tails } \\
\text { (III) }\end{array}$ & $(\mathrm{II})+(\mathrm{III})$ & $\begin{array}{l}\text { Excluding } \\
5 \% \text { tails } \\
\text { (IV) }\end{array}$ & $(\mathrm{II})+(\mathrm{IV})$ \\
\hline Status quo & -1.723 & -1.833 & -1.34 & -1.389 & -0.808 & -0.751 \\
\hline Lower Bound & -2.485 & -2.578 & -1.963 & -2.032 & -1.085 & -1.013 \\
\hline Upper Bound & -1.117 & -1.259 & -0.822 & -0.842 & -0.569 & -0.526 \\
\hline Solar & 0.082 & 0.075 & 0.058 & 0.055 & 0.036 & $0.030^{a}$ \\
\hline Lower Bound & 0.021 & 0.013 & 0.009 & 0.01 & 0.005 & -0.001 \\
\hline Upper Bound & 0.148 & 0.14 & 0.107 & 0.102 & 0.067 & 0.063 \\
\hline Biomass & -0.092 & -0.093 & -0.07 & -0.067 & -0.049 & -0.054 \\
\hline Lower Bound & -0.153 & -0.153 & -0.113 & -0.108 & -0.077 & -0.084 \\
\hline Upper Bound & -0.038 & -0.04 & -0.03 & -0.03 & -0.021 & -0.025 \\
\hline$\%$ of renewable energy & 0.01 & 0.009 & 0.007 & 0.007 & 0.005 & 0.005 \\
\hline Lower Bound & 0.006 & 0.005 & 0.004 & 0.004 & 0.003 & 0.003 \\
\hline Upper Bound & 0.015 & 0.014 & 0.011 & 0.011 & 0.007 & 0.007 \\
\hline New green jobs (thousands) & 0.059 & 0.059 & 0.047 & 0.045 & 0.032 & 0.030 \\
\hline Lower Bound & 0.033 & 0.033 & 0.026 & 0.025 & 0.018 & 0.016 \\
\hline Upper Bound & 0.093 & 0.093 & 0.072 & 0.069 & 0.048 & 0.047 \\
\hline
\end{tabular}

\footnotetext{
${ }^{a}$ Zero null hypothesis can be rejected with $p<0.10$.
} 
Table A5: Conditional Logit specifications on stated choices — assuming that \% of renewable energy and new green jobs attributes are continuous

\begin{tabular}{|c|c|c|c|c|c|c|}
\hline & $\begin{array}{l}\text { Entire sample } \\
\text { (I) }\end{array}$ & $\begin{array}{c}\text { Excluding } \\
>8 \text { hh members } \\
\text { (II) }\end{array}$ & $\begin{array}{l}\text { Excluding } \\
1 \% \text { tails }^{d} \\
\text { (III) }\end{array}$ & (II) $+(\mathrm{III})$ & $\begin{array}{l}\text { Excluding } \\
5 \% \text { tails }^{d} \\
\quad(\mathrm{IV})\end{array}$ & $(\mathrm{II})+(\mathrm{IV})$ \\
\hline 1 if status quo option & $\begin{array}{c}-0.907^{* * *} \\
(0.121)\end{array}$ & $\begin{array}{c}-0.942^{* * *} \\
(0.123)\end{array}$ & $\begin{array}{c}-0.951^{* * *} \\
(0.123)\end{array}$ & $\begin{array}{c}-0.991^{* * *} \\
(0.125)\end{array}$ & $\begin{array}{c}-1.057^{* * *} \\
(0.128)\end{array}$ & $\begin{array}{c}-1.082^{* * *} \\
(0.130)\end{array}$ \\
\hline 1 if $\operatorname{solar}^{a}$ & $\begin{array}{l}0.219^{* * *} \\
(0.0595)\end{array}$ & $\begin{array}{l}0.213^{* * *} \\
(0.0601)\end{array}$ & $\begin{array}{l}0.220^{* * *} \\
(0.0606)\end{array}$ & $\begin{array}{l}0.214^{* * *} \\
(0.0612)\end{array}$ & $\begin{array}{l}0.213^{* * *} \\
(0.0634)\end{array}$ & $\begin{array}{c}0.202^{* *} \\
(0.0639)\end{array}$ \\
\hline 1 if biomass $^{a}$ & $\begin{array}{l}-0.203^{* *} \\
(0.0659)\end{array}$ & $\begin{array}{l}-0.210^{* *} \\
(0.0665)\end{array}$ & $\begin{array}{l}-0.207^{* *} \\
(0.0670)\end{array}$ & $\begin{array}{l}-0.214^{* *} \\
(0.0677)\end{array}$ & $\begin{array}{l}-0.219^{* *} \\
(0.0700)\end{array}$ & $\begin{array}{l}-0.223^{* *} \\
(0.0704)\end{array}$ \\
\hline$\%$ of renewable energy ${ }^{b}$ & $\begin{array}{l}0.0223^{* * *} \\
(0.00314)\end{array}$ & $\begin{array}{l}0.0222^{* * *} \\
(0.00317)\end{array}$ & $\begin{array}{l}0.0228^{* * *} \\
(0.00319)\end{array}$ & $\begin{array}{l}0.0227^{* * *} \\
(0.00323)\end{array}$ & $\begin{array}{l}0.0216^{* * *} \\
(0.00334)\end{array}$ & $\begin{array}{l}0.0221^{* * *} \\
(0.00337)\end{array}$ \\
\hline New green jobs (thousands) ${ }^{c}$ & $\begin{array}{l}0.130^{* * *} \\
(0.0329)\end{array}$ & $\begin{array}{l}0.130^{* * *} \\
(0.0333)\end{array}$ & $\begin{array}{l}0.137^{* * *} \\
(0.0335)\end{array}$ & $\begin{array}{l}0.137^{* * *} \\
(0.0339)\end{array}$ & $\begin{array}{l}0.148^{* * *} \\
(0.0351)\end{array}$ & $\begin{array}{l}0.145^{* * *} \\
(0.0354)\end{array}$ \\
\hline $\begin{array}{l}\text { Hypothetical bimonthly } \\
\text { electricity bill (thousand MX pesos) }\end{array}$ & $\begin{array}{c}-2.148^{* * *} \\
(0.238)\end{array}$ & $\begin{array}{c}-2.274^{* * *} \\
(0.247)\end{array}$ & $\begin{array}{c}-2.963^{* * *} \\
(0.281)\end{array}$ & $\begin{array}{c}-3.173^{* * *} \\
(0.293)\end{array}$ & $\begin{array}{c}-4.602^{* * *} \\
(0.391)\end{array}$ & $\begin{array}{c}-4.601^{* * *} \\
(0.392)\end{array}$ \\
\hline Respondents & 199 & 195 & 195 & 191 & 177 & 174 \\
\hline Observations & 7236 & 7092 & 7068 & 6924 & 6450 & 6347 \\
\hline ll & -2232.4 & -2181.8 & -2162.8 & -2110.3 & -1967.9 & -1931.3 \\
\hline $\mathrm{AIC}$ & 4476.8 & 4375.7 & 4337.6 & 4232.6 & 3947.8 & 3874.5 \\
\hline $\mathrm{BIC}$ & 4518.1 & 4416.9 & 4378.8 & 4273.6 & 3988.5 & 3915.1 \\
\hline \multicolumn{7}{|c|}{$\begin{array}{l}\text { Standard errors in parentheses. }{ }^{*} p<0.10,{ }^{* *} p<0.05,{ }^{* * *} p<0.001 . \\
{ }^{a} \text { Reference category: } 50 / 50 \text { combination of solar and biomass. } \\
b \% \text { of renewable energy is assumed a continuous variable in specifications reported in table A5. } \\
{ }^{c} \text { New green jobs is assumed a continuous variable in specifications reported in table A5. }\end{array}$} \\
\hline
\end{tabular}


Table A6: Marginal willingness to pay (bimonthly, 2018 thousand Mexican pesos) and 95\% confidence intervals resulting from Conditional Logit specifications reported in table A5

\begin{tabular}{|c|c|c|c|c|c|c|}
\hline MWTP for & $\begin{array}{l}\text { Entire sample } \\
\text { (I) }\end{array}$ & $\begin{array}{c}\text { Excluding } \\
>8 \text { hh members } \\
(\text { II })\end{array}$ & $\begin{array}{l}\text { Excluding } \\
1 \% \text { tails } \\
\text { (III) }\end{array}$ & (II) +(III) & $\begin{array}{c}\text { Excluding } \\
5 \% \text { tails } \\
\text { (IV) }\end{array}$ & $(\mathrm{II})+(\mathrm{IV})$ \\
\hline Status quo & -0.423 & -0.414 & -0.321 & -0.312 & -0.23 & -0.235 \\
\hline Lower Bound & -0.574 & -0.559 & -0.424 & -0.409 & -0.297 & -0.303 \\
\hline Upper Bound & -0.303 & -0.299 & -0.234 & -0.23 & -0.172 & -0.176 \\
\hline Solar & 0.102 & 0.094 & 0.074 & 0.067 & 0.046 & 0.044 \\
\hline Lower Bound & 0.05 & 0.045 & 0.037 & 0.032 & 0.021 & 0.018 \\
\hline Upper Bound & 0.16 & 0.148 & 0.117 & 0.107 & 0.074 & 0.072 \\
\hline Biomass & -0.094 & -0.092 & -0.07 & -0.068 & -0.048 & -0.048 \\
\hline Lower Bound & -0.161 & -0.155 & -0.116 & -0.111 & -0.078 & -0.079 \\
\hline Upper Bound & -0.034 & -0.035 & -0.026 & -0.026 & -0.018 & -0.019 \\
\hline$\%$ of renewable energy & 0.01 & 0.01 & 0.008 & 0.007 & 0.005 & 0.005 \\
\hline Lower Bound & 0.007 & 0.007 & 0.005 & 0.005 & 0.003 & 0.003 \\
\hline Upper Bound & 0.015 & 0.014 & 0.011 & 0.01 & 0.006 & 0.007 \\
\hline New green jobs (thousands) & 0.061 & 0.057 & 0.046 & 0.043 & 0.032 & 0.031 \\
\hline Lower Bound & 0.032 & 0.03 & 0.025 & 0.023 & 0.018 & 0.017 \\
\hline Upper Bound & 0.097 & 0.092 & 0.072 & 0.067 & 0.049 & 0.049 \\
\hline
\end{tabular}

